\title{
Article \\ The bis(Biphenyl)phosphorus Fragment in Trivalent and Tetravalent P-Environments
}

\author{
Jonas Hoffmann ${ }^{1}\left(\mathbb{D}\right.$, Daniel Duvinage ${ }^{2}(\mathbb{D})$, Enno Lork ${ }^{2}$ and Anne Staubitz ${ }^{1, *(\mathbb{D})}$ \\ 1 Institute for Organic and Analytical Chemistry, University of Bremen, Leobener Straße 7, \\ D-28359 Bremen, Germany; jonas.hoffmann@uni-bremen.de \\ 2 Institute for Inorganic Chemistry and Crystallography, University of Bremen, Leobener Straße 7, \\ D-28359 Bremen, Germany; duvinage@uni-bremen.de (D.D.); elo@uni-bremen.de (E.L.) \\ * Correspondence: staubitz@uni-bremen.de; Tel.: +49-421-218-63210
}

check for updates

Citation: Hoffmann, J.; Duvinage, D. Lork, E.; Staubitz, A. The bis(Biphenyl)phosphorus Fragment in Trivalent and Tetravalent P-Environments. Inorganics 2021, 9,

82. https://doi.org/ 10.3390/inorganics 9110082

Academic Editor: Axel Klein

Received: 13 October 2021

Accepted: 9 November 2021

Published: 16 November 2021

Publisher's Note: MDPI stays neutral with regard to jurisdictional claims in published maps and institutional affiliations.

Copyright: (c) 2021 by the authors. Licensee MDPI, Basel, Switzerland. This article is an open access article distributed under the terms and conditions of the Creative Commons Attribution (CC BY) license (https:// creativecommons.org/licenses/by/ $4.0 /)$.

\begin{abstract}
Diaryl substituted phosphorus (III) compounds are commonly used motifs in synthesis. Although the basic synthetic routes to these molecules starting from $\mathrm{PCl}_{3}$ are well reported, sterically hindered aryl substituents can be difficult to introduce, especially if the $\mathrm{P}$ atom is in ortho position to another group. This work explores the chemistry of the bis(biphenyl)phosphorus(III) fragment. As third substituents, $\mathrm{H}, \mathrm{M}, \mathrm{Cl}, \mathrm{NR}_{2}$, two group 14 element substituents and also Li were introduced in high-yielding processes offering a wide chemical variety of the bis(biphenyl) phosphine motif. In addition, also a tetravalent phosphine borane adduct was isolated. All structures were thoroughly investigated by heteronuclear NMR spectroscopic analysis. Furthermore, the reaction conditions are discussed in connection with the structures and four crystal structures of the aminophosphine, phosphine, phosphine borane and phosphide are provided. The latter crystallized as a dimer with a unique planar $\mathrm{P}_{2} \mathrm{Li}_{2}$ ring, which is stabilized by the non-covalent $\mathrm{C} \cdots \mathrm{Li}$ interaction arising from the biphenyl motif and represents a rare example of a donor-free planar $\mathrm{P}_{2} \mathrm{Li}_{2}$ ring.
\end{abstract}

Keywords: organophosphorus chemistry; phosphide; phosphine; ligand; phosphine borane; aminophosphine; silylphosphine; stannylphosphine

\section{Introduction}

Phosphorus diaryl fragments are very common motifs in reagents for the preparation of ligands for metal complexes. Their use in catalysis is therefore undisputed. These fragments also occur in inorganic polymers and rings [1-3]. The most common ones among these are trivalent diarylphosphines, $\mathrm{Ar}_{2} \mathrm{PH}$, the corresponding tetravalent phosphine boranes, $\mathrm{R}_{2} \mathrm{PH}-\mathrm{BH}_{3}$, the corresponding lithiated species, $\mathrm{Ar}_{2} \mathrm{PLi}$, and the aminospecies $\mathrm{Ar}_{2} \mathrm{PNR}_{2}$. There are well-established ways in which all these species can be obtained and how they are synthetically connected (Scheme 1).

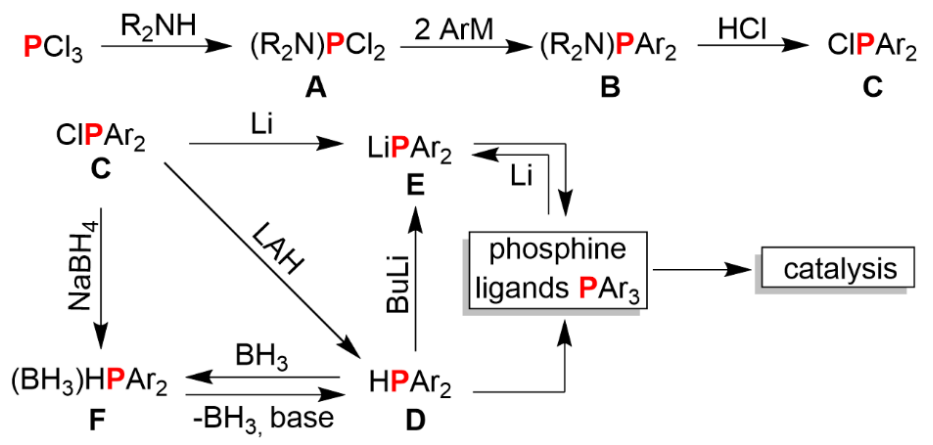

Scheme 1. Synthesis of diarylphosphine, diarylphosphides and diarylphosphine borane. Abbreviation: Lithium aluminum hydroxide ( $\mathrm{LAH})$, butyl lithium (BuLi). 
Aminophosphines are classically prepared by the reaction of substituted amines with phosphorous trichloride and potentially followed by the nucleophilic substitution with a carbonucleophile [4]. They represent a special class of phosphines as they behave as ambident reagents due to the presence of a Lewis soft $(\mathrm{P})$ and a Lewis hard $(\mathrm{N})$ basic atom connected to each other. Hence, in combination with soft Lewis acids, the phosphorus will serve as Lewis basic center and consequently, hard Lewis acids will coordinate with the nitrogen atoms [5]. The special bonding nature of aminophosphine is defined by the $\pi$-electron transfer from the nitrogen atom to the phosphorus and, therefore, the basicity of aminophosphines is similar or higher to tertiary alkylamines or alkylphosphines. However, aminophosphines are not as reactive as tertiary alkylphosphines, which are very susceptible to oxidation, which indicates that steric hindrance at the phosphorus and/or nitrogen are more important factors to their reactivity than electronic effects [4].

Diarylphosphines are commonly synthesized from triarylphosphines, which are reduced to the respective diarylphosphide and quenched with a protic medium [6,7]. Diarylphosphines often only serve as precursors for further ligand synthesis. However, diphenylphosphine is used in Michael addition reactions for activated alkenes [8], in a radical fashion to ketenes [9] or as precursor for Wittig reagents [10]. Moreover, diarylphosphines can be introduced to an aromatic system by C-P coupling using an aryl halide and palladium [11,12] or nickel [13] catalysis.

As described above diarylphosphides are prepared from reductive $\mathrm{C}-\mathrm{P}$ bond cleavage of a triaryl phosphine, by reduction of a diarylchlorophosphine with a hydride-based reductant (e.g., LAH) or deprotonation of diarylphosphines with butyllithium (BuLi). They represent precursors for prominent ligands such as 1,2-bis(diphenylphosphino)methane (dppm) 1,2-bis(diphenylphosphino)ethane (dppe) [1]. Moreover, diarylphosphides can also serve as reagents. In particular, it was shown that lithium diphenylphosphide supports the dihydroxylation of $\alpha$-hydroxyketones [14] or the dealkylation of alkyl aryl ethers $[15,16]$.

As diarylphosphines quickly undergo oxidation, they are commonly protected with borane to form diarylphosphine boranes $[17,18]$. As this class of species is more reactive towards substitution, it is widely used in catalyst-free Staudinger ligation [19], as stereogenic precursor for ligand synthesis [20], for the preparation of alkynylphosphine derivatives [21]. Diarylphosphine boranes can be coupled to vinyl triflates or aryl halides to cyclic or acyclic vinyl triflates using palladium catalyst to access the respective tertiary phosphine boranes [22-24].

As all these diaryl fragments are mainly used en route to other compounds, their structure is very important not only for the assessment of their reactivity but also for an understanding of their steric impact on the target molecules. As the structure (chemical and electronic) is key for their function, these reagents deserve in-depth investigations.

The most commonly used aryl group is phenyl, but less is known about other aryl groups. However, one very important aryl motif in the context of phosphine chemistry is the biaryl motif, in which phosphorus is bound ortho to the phenyl group. Ligands of this type are for example Buchwald ligands, which facilitate the reductive elimination in the catalytic cycle.

While the synthesis of such ligands is primarily based on the preparation of a carbonucleophile using both Grignard-based [25,26] and organolithium-based [27,28] routes, which are further reacted with chlorodialkylphosphine (catalyzed by $\mathrm{CuCl}$ ), the isolation of any nucleophilic phosphide with already formed carbon scaffold remains elusive. In particular, the bis(biphenyl)phosphine has been successfully deployed as resin-bound ligand in cross coupling reactions [29] but the bis(biphenyl)phosphine and its derivatives have not been isolated yet. Various trivalent and tetravalent bis(biphenyl)phosphine derivatives could serve as a starting point for the synthesis of a novel ligand class that is based on the bis(biphenyl)phosphine motif.

As a bis(biphenyl)phosphine motif has great potential as a ligand for catalysis, we present its most common ones among these are trivalent diarylphosphines, $\mathrm{Ar}_{2} \mathrm{PH}$, the 
corresponding tetravalent phosphine boranes, $\mathrm{R}_{2} \mathrm{PH}-\mathrm{BH}_{3}$, the corresponding lithiated species, $\mathrm{Ar}_{2} \mathrm{PLi}$, starting from the aminospecies $\mathrm{Ar}_{2} \mathrm{PNR}_{2}$.

\section{Results}

\subsection{Syntheses}

2.1.1. Synthesis of bis(Biphenyl)diisopropylamino Phosphine (A)

The synthesis of the lithiated bis(biphenyl)phosphide (E) was already reported as a consecutive reaction [29]. The procedure included a bromide-lithium exchange of 2bromobiphenyl, followed by the reaction with $N, N$-diethylphosphoramidous dichloride (A) to form the protected diarylamino phosphine $\left(\mathbf{B}_{\mathrm{Et}}\right)$. This was deprotected with hydrogen chloride to form the diarylchlorophosphine $(\mathbf{C})$ followed by reduction with lithium wire to give the lithium bis(biphenyl)phosphide (E) (Scheme 2) [29].

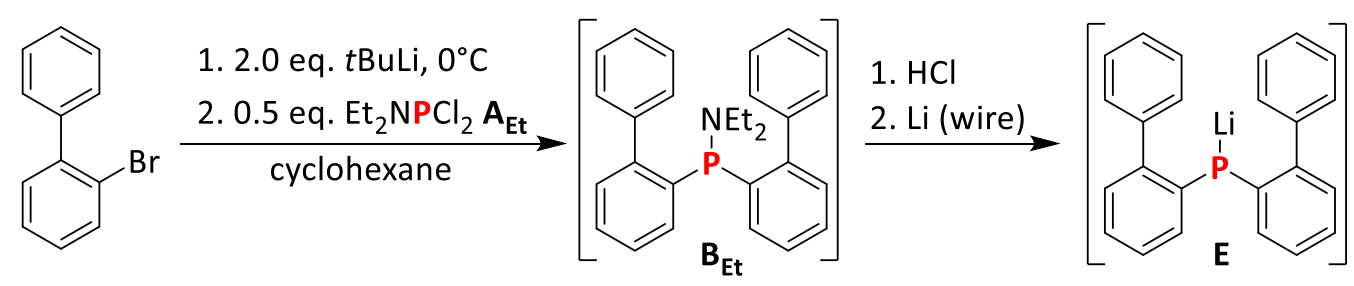

Scheme 2. The synthetic procedure to lithium diarylphosphide E according to Le Drian and coworkers [29].

However, there were no isolated species reported in this reference. Therefore, the steps were investigated in detail. After the initial step could not be reproduced in our hands using these conditions with another P precursor, the formation of the diarylamino phosphine B succeeded with the commercially available Grignard reagent in $n$-pentane as a solvent (Scheme 3).<smiles>Brc1ccccc1-c1ccccc1</smiles>

in $\mathrm{Et}_{2} \mathrm{O}$

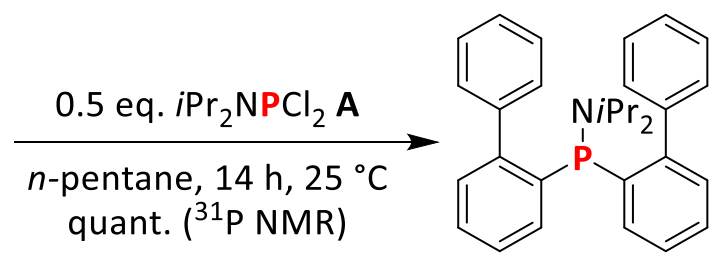

B, $97 \%$

Scheme 3. Synthesis of the bis(biphenyl-2-yl)-N,N-diisopropylphosphanamine B.

Although the reaction mixture was inhomogeneous, ${ }^{31} \mathrm{P}$ NMR experiments indicated that the disubstituted product $\mathbf{A}(\delta=22.5 \mathrm{ppm})$ was formed selectively. This was confirmed since we could isolate the product in excellent yield and purity. Product $\mathbf{B}$ showed stability against moisture and air which was not observed for its phenyl derivative [30]. Therefore, it was concluded that the biphenyl ligands sterically shield the phosphorus atom which was confirmed by single-crystal X-ray analysis (see Section 2.2). The phenyl derivative of bis(biphenyl)diisopropylamino phosphine is widely used as ligand for transition-metal catalyzed cross-coupling reactions [31-33] or for coordination chemistry [34,35].

\subsubsection{Synthesis of $b i s$ (Biphenyl)chlorophosphine}

The diarylamino phosphine was converted to the respective phosphine chloride $\mathbf{C}$ by using an excess of hydrogen chloride in an etheric solution (Scheme 4). 


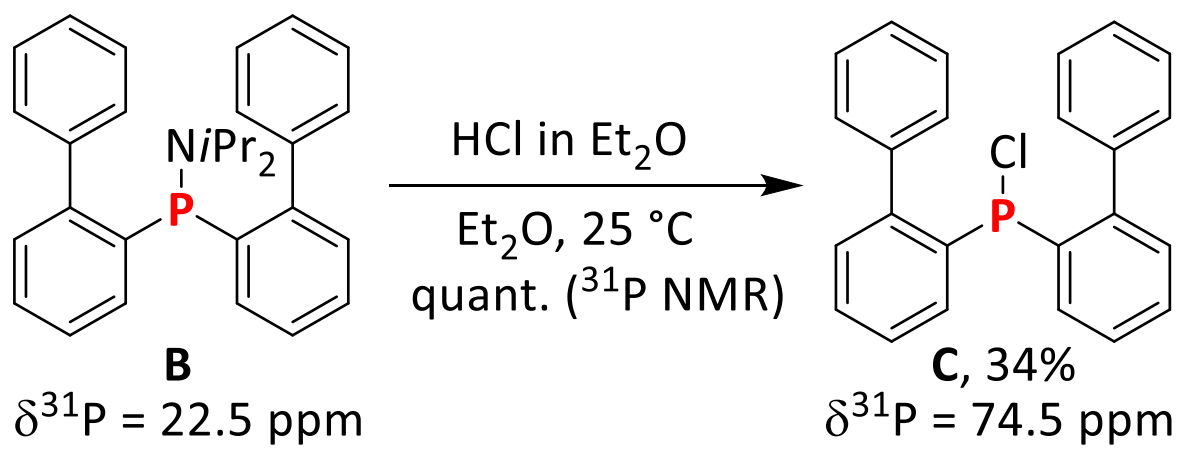

Scheme 4. Synthesis of the bis(biphenyl)chlorophosphine (C).

The ${ }^{31} \mathrm{P}$ NMR spectrum of the reaction mixture indicated a quantitative conversion to product $\mathbf{C}$, which was obtained after filtration from the ammonium salts. The isolation of this molecule succeeded using high temperature, high vacuum Kugelrohr $\left(180{ }^{\circ} \mathrm{C}\right.$, $3.2 \times 10^{-2}$ mbar) distillation and resulted in the pure compound but in a low yield of $34 \%$. Over the course of this distillation, side products, which are likely to be phosphinic chlorides $(\delta=34.0 \mathrm{ppm})$ and phosphine oxides $\left(\delta=15.9\left({ }^{1} J_{\mathrm{PH}}=503.3 \mathrm{~Hz}\right) \mathrm{ppm}\right)$, occurred. However, the isolation of this product was not pursued further as in situ performed ${ }^{31} \mathrm{P}$ NMR analysis showed quantitative conversion.

\subsubsection{Synthesis of bis(Biphenyl)phosphine}

Because of the quantitative conversion of $\mathbf{B}$ to $\mathbf{C}$, this chlorophosphine could be directly reduced with lithium aluminum hydride in a THF solution to give the diarylphosphine $\mathbf{D}$ in $91 \%$ yield (Scheme 5 ).

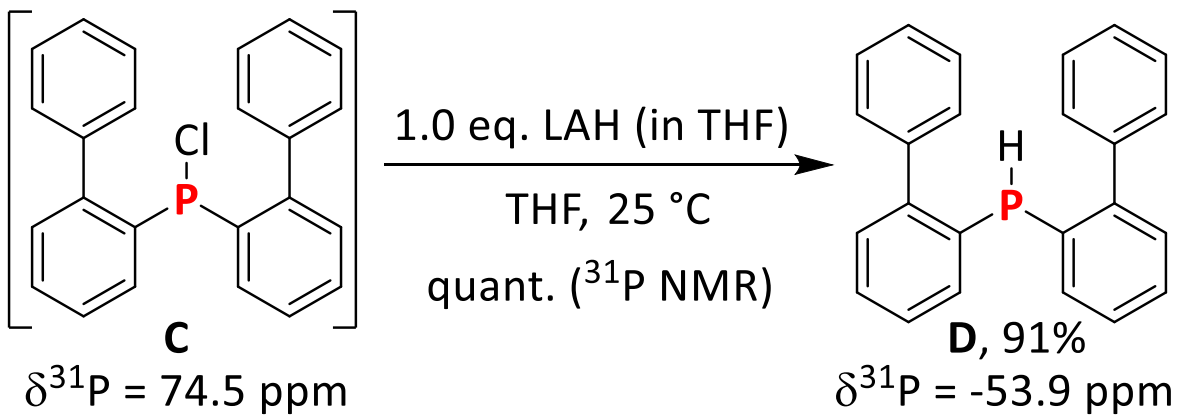

Scheme 5. Reduction of the chlorophosphine $\mathbf{C}$ with LAH solution gave the phosphine $\mathbf{D}$ as the pure product after distillation.

The reduction resulted in the full conversion as determined by ${ }^{31} \mathrm{P}$ NMR analysis. Initial attempts to purify the product by column chromatography failed as the phosphine $\mathbf{D}$ oxidized readily. However, the isolation of the compound $\mathbf{D}$ succeeded using high temperature $\left(160^{\circ} \mathrm{C}\right)$, high vacuum $\left(10^{-2} \mathrm{mbar}\right)$ inert Kugelrohr distillation. After cooling the product, it crystallized readily (the crystal structure is discussed in Section 2.2).

\subsubsection{Synthesis of bis(Biphenyl)phosphine Borane Adduct F}

Since the phosphine $\mathbf{D}$ was not stable against oxidation, it was stabilized by transforming it to the respective phosphine-borane $\mathbf{F}$. To access compound $\mathbf{F}$, two synthetic routes were successfully developed: First by the successive reduction with lithium aluminum hydride to access the phosphine $\mathbf{D}$ (vide supra) and further protection with the borane THF adduct as a reagent. Secondly, the direct reduction of the chlorophosphine $\mathbf{C}$ with lithium borohydride succeed in high yields (Scheme 6). 


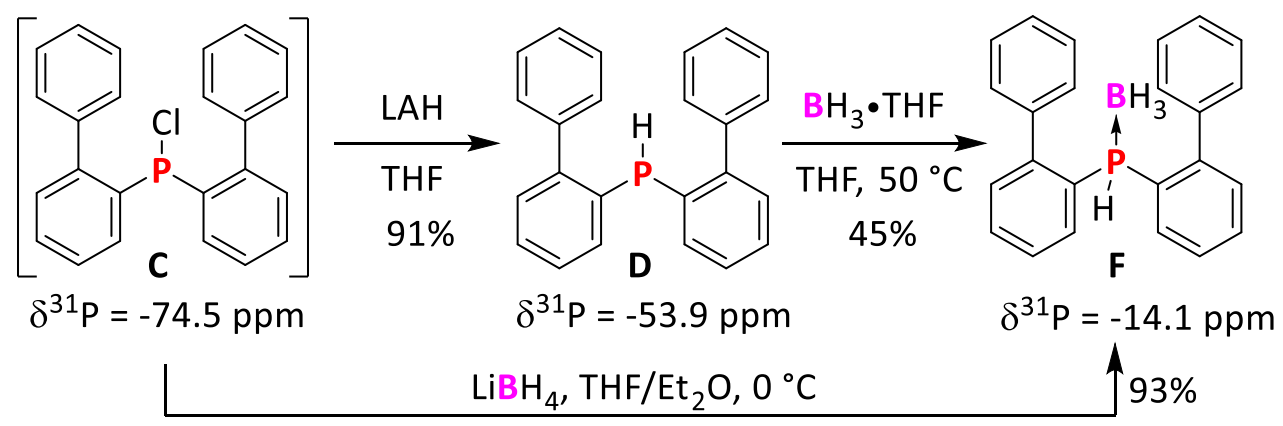

Scheme 6. Synthesis of the bis(biphenyl)phosphine borane (F) starting from chlorophosphine C.

The protection of the phosphine $\mathbf{D}$ with the borane THF adduct at $25{ }^{\circ} \mathrm{C}$ initially showed no conversion. Upon heating to $50^{\circ} \mathrm{C}$, it was possible to obtain nearly quantitative conversion to the phosphine borane $\mathbf{F}$ as determined by ${ }^{31} \mathrm{P}$ NMR $(\delta=-14.1 \mathrm{ppm}$, see Figure S23). The borane adduct $\mathbf{D}$ could be isolated by crystallization in a $45 \%$ yield. However, a direct reduction/borylation procedure using lithium borohydride in THF gave $\mathbf{D}$ in an excellent yield of $93 \%$ after crystallization. The resulting crystals of $\mathbf{D}$ were suitable for X-ray analysis (see Section 2.2). However, the phosphine borane $\mathbf{D}$ was moisture-, airand temperature-sensitive and must be stored under inert conditions at low temperature.

\subsubsection{Synthesis and Reactivity of Lithium bis(Biphenyl)phosphide}

The synthesis of the lithium bis(biphenyl)phosphide $\mathbf{E}$ by reducing the chlorophosphine $\mathbf{C}$ directly with lithium [29] was unsuccessful initially, because $\mathrm{C}-\mathrm{P}$ bond cleavage occurred to give biphenylphosphine and biphenyl. Therefore, the formation of phosphide was pursued by deprotonation from the respective phosphine with $n \mathrm{BuLi}$ (Scheme 7).<smiles>c1ccc(-c2ccccc2Pc2ccccc2-c2ccccc2)cc1</smiles>

D $\delta^{31} \mathrm{P}=-53.9 \mathrm{ppm}$

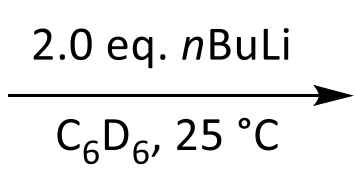<smiles>[Te]P(c1ccccc1-c1ccccc1)c1ccccc1-c1ccccc1</smiles>

E, 99\%

$$
\delta^{31} \mathrm{P}\left(\mathrm{THF} / \mathrm{C}_{6} \mathrm{D}_{6}\right)=-36.0 /-52.4 \mathrm{ppm}
$$

Scheme 7. Metalation of phosphine $\mathbf{D}$ with $n \mathrm{BuLi}$ gave the phosphide $\mathbf{E}$. The phosphide was only slightly soluble in $\mathrm{C}_{6} \mathrm{D}_{6}$; therefore, no ${ }^{7} \mathrm{Li}$ NMR signal was found. In THF, the ${ }^{7} \mathrm{Li}$ and ${ }^{31} \mathrm{P}$ NMR species were clearly observable but, in the latter, slightly shifted.

When the reaction was performed in deuterated benzene precipitate formed instantaneously upon the addition of $n \mathrm{BuLi}$ and an intense orange color was observed. The full conversion to the poorly soluble phosphide $\mathbf{E}$ was achieved by using two equivalents of $n \mathrm{BuLi}$ at $25^{\circ} \mathrm{C}$ resulting in the formation of the product in excellent yield $(99 \%)$. The phosphide was stable at $25^{\circ} \mathrm{C}$ in the glove box but decomposed rapidly upon mixing with ethers or other solvents except for benzene/toluene or aliphatic solvents.

The ${ }^{31} \mathrm{P}\left\{{ }^{1} \mathrm{H}\right\}$ NMR shift of $\mathbf{E}$ was strongly dependent on the solvent and was observed as a broad signal in $\mathrm{C}_{6} \mathrm{D}_{6}(\delta=-52.4 \mathrm{ppm})$. In a mixture with THF, the signal was shifted downfield $(\delta=-36.0 \mathrm{ppm})$ due to the coordination of the solvent (see Figures S16 and S17). Crystals of phosphide $\mathbf{E}$ without any coordinating solvent could be grown and revealed that the product crystallized as a dimer with each phosphorus atom interacting with two lithium atoms forming a $\mathrm{P}_{2} \mathrm{Li}_{2}$ planar ring (see below). 
To highlight the reactive nature of the phosphide, it was reacted with trimethylsilyl chloride to give the respective silyl phosphine but it did not react with its heavier congener trimethyltin chloride (Scheme 8).

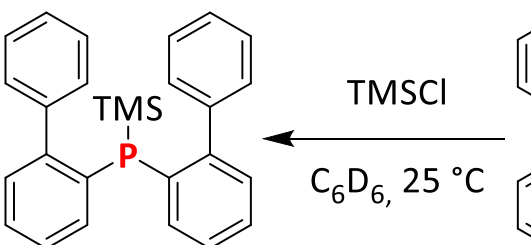<smiles>[13CH3][13CH3]</smiles>

$\delta^{31} \mathrm{P}=-69.8 \mathrm{ppm}$<smiles>c1ccc(-c2ccccc2[Tl]c2ccccc2-c2ccccc2)cc1</smiles>

E<smiles>CSP(c1ccccc1)c1ccccc1-c1ccccc1P(C)c1ccccc1</smiles>

H

Scheme 8. Reaction of phosphide $\mathrm{E}$ with two trimethyl tetrel chlorides.

The latter reaction did not occur although the reaction mixture was treated at an elevated temperature $\left(80^{\circ} \mathrm{C}\right)$. This clearly indicated that the phosphide $\mathbf{E}$ had an organometallic 'hard' character and therefore, the reaction with the rather 'soft' trimethyltin chloride did not proceed. With this information in hand, the trimethylstannyl phosphine $\mathbf{H}$ could be accessed from the 'soft' phosphine D using (dimethylamino)trimethyltin as a 'soft' trimethylstannyl transfer reagent [36] (Scheme 9).<smiles>c1ccc(-c2ccccc2Pc2ccccc2-c2ccccc2)cc1</smiles>

D

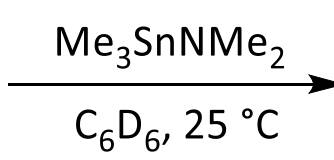<smiles>C[As](c1ccccc1)c1ccccc1-c1ccccc1-c1ccccc1</smiles>

H, $99 \%$

$\delta^{31} \mathrm{p}=-53.9 \mathrm{ppm}$

$\delta^{31} \mathrm{P}=-62.0 \mathrm{ppm}$

Scheme 9. Stannylation of phosphine D with (dimethylamino)trimethyltin.

The sole byproduct formed in this reaction, dimethylamine, could be easily removed by applying a vacuum leaving behind the pure product in an excellent yield. Compared to the silyl phosphine $(\delta=-69.8 \mathrm{ppm})$, the stannyl phosphine displayed a deshielded phosphorus atom with a ${ }^{31} \mathrm{P}$ NMR shift of $\delta=-62.0 \mathrm{ppm}$. Neither compound could by crystallized.

\subsection{Crystal Structures}

The crystals of bis(biphenyl)diisoproylamino phosphine (B), bis(biphenyl)phosphine (D), bis(biphenyl)phosphine borane adduct (F) and lithium bis(biphenyl)phosphide (E) could be grown and they were characterized by single-crystal X-ray analysis (Figure 1, Table 1). In the following, the structures will be discussed and a conclusion with respect to their reactivity will be outlined.

While structure B crystallized in a triclinic crystal system, the other structures were found in a monoclinic crystal system. Structure B has a P-N bond length of 1.6917(7) $\AA$, which is a typical value for $\mathrm{P}(\mathrm{III})-\mathrm{N}$ bond systems similar to the 1,2-bis(diphenylphosphino) (benzyl)aminoethane (1.68(1) $\AA$ ) [37]. Interestingly, this structure did not oxidize whereas its phenyl-derivative was prone to oxidation. Although the sum of angles at the phosphorus atom $\left(\Sigma=307.71^{\circ}\right)$ indicated sufficient space for oxidation events, the similar biphenyl of dialkylbiphenyl phosphines, also referred to as Buchwald ligands, [38], is known to prevent the ligand's oxidation effectively [39]. The C-P-C angle (99.39 $\left.{ }^{\circ}\right)$, of structure B was the lowest value in the here reported quartet. The biphenyl groups of $\mathbf{B}$ showed internal twisting, as indicated by the respective large torsion angles $\left(-56.2^{\circ}\right.$ and $\left.-55.6^{\circ}\right)$. 


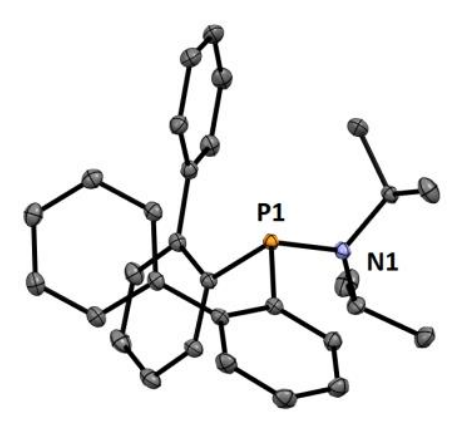

B

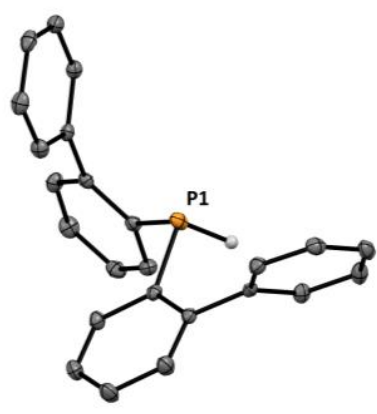

D

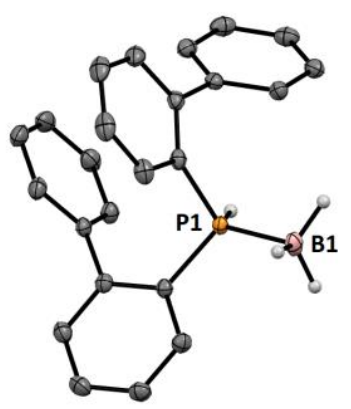

F

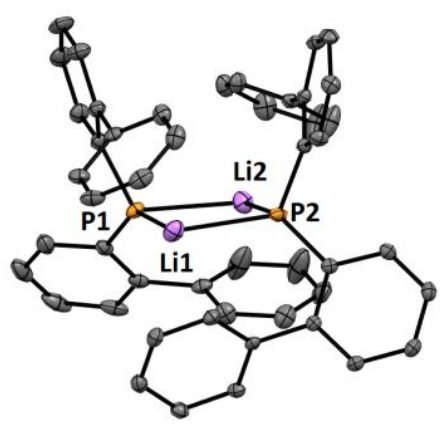

E

Figure 1. Overview of molecule structures. All carbon-bonded hydrogen atoms were removed for clarity.

Table 1. Overview key crystal structure details for B, D, F and E.

\begin{tabular}{ccccc}
\hline & $\mathbf{B}$ & $\mathbf{D}$ & $\mathbf{F}$ & $\mathbf{E}$ \\
\hline crystal system & triclinic & monoclinic & monoclinic & monoclinic \\
space group & $\mathrm{P}-1$ & $\mathrm{P} 2_{1} / \mathrm{c}$ & $\mathrm{P} 2_{1} / \mathrm{c}$ & $\mathrm{P} 2_{1} / \mathrm{n}$ \\
P-X bond length & $1.6917(7) \AA$ & $1.32(2) \AA$ & $1.30(1) \AA /$ & $2.503(2) / 2.490(3) \AA$ \\
P-C bond length & $1.8491(6) \AA$ & $1.837(1) \AA$ & $1.926(1) \AA$ & $2.507(3) / 2.567(2) \AA$ \\
P-C bond length & $1.8546(9) \AA$ & $1.847(1) \AA$ & $1.812(1) \AA$ & $1.820(1) / 1.822(1) \AA$ \\
C C-P-C $_{\mathbf{P}}$ & $99.39^{\circ}$ & $102.30^{\circ}$ & $104.93^{\circ}$ & $1.821(1) / 1.824(1) \AA$ \\
申biaryl $_{\mathbf{1}}$ & $307.71^{\circ}$ & $297.23^{\circ}$ & $316.13^{\circ}$ & $104.33^{\circ} / 103.58^{\circ}$ \\
申biaryl $_{\mathbf{2}}$ & $-56.2(1)^{\circ}$ & $-65.2(2)^{\circ}$ & $-49.7(1)^{\circ}$ & $66.2(2)^{\circ} /-69.3(2)^{\circ}$ \\
\hline & $-55.6(1)^{\circ}$ & $-65.6(2)^{\circ}$ & $-113.3(1)^{\circ}$ & $-76.3(2)^{\circ} /-58.6(2)^{\circ}$ \\
\hline
\end{tabular}

The crystal structure of phosphine $\mathbf{D}$ had the space group $\mathrm{P} 2{ }_{1} / \mathrm{c}$. The sum of angles at the phosphorus atom $\left(\Sigma \mathrm{P}=297.23^{\circ}\right)$ was the lowest from the here presented structures. As visualized, the geometry of the biphenyl ligand was so spacious that still chemical modification at the phosphorus atom was possible and the structure underwent oxidation rapidly. Therefore, it was protected with borane to form structure $\mathbf{F}$, which was found in space group $\mathrm{P} 2{ }_{1} / \mathrm{c}$. The key interest in this system was the $\mathrm{P}-\mathrm{B}$ bond length, which was determined as 1.926(1) $\AA$. This was similar to a common P-B bond length of 1.915(3) $\AA$ in bis(ortho-N,N-dimethylaniline)phosphine borane [40].

The lithium bis(biphenyl)phosphide (E) crystalized as a phosphide-bridged dimer in the space group $\mathrm{P} 21 / \mathrm{n}$. The central unit of the crystal structure was a quasi-planar four-membered rhombic $\mathrm{P}_{2} \mathrm{Li}_{2}$ ring with a small dihedral angle $\left(\phi(\mathrm{P}-\mathrm{Li}-\mathrm{P}-\mathrm{Li})=4.73^{\circ}\right)$ and nearly orthogonal Li-P-Li angles $\left(\angle(\mathrm{Li} 1-\mathrm{P} 1-\mathrm{Li} 2)=80.60^{\circ}, \angle(\mathrm{Li} 1-\mathrm{P} 2-\mathrm{Li} 2)=82.18^{\circ}\right)$. The biphenyl ligands filled the edges in this ring structure in an orthogonal fashion.

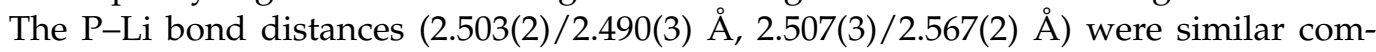
pared to other reported organo arylphosphides [41]. For the carbon atoms of the second biphenyl ring and the lithium cation $\bullet \bullet \pi$ interaction, similar to the reported $[\{\operatorname{Li}(2,4$, $\left.\left.\left.6-t \mathrm{Bu}_{3} \mathrm{C}_{6} \mathrm{H}_{2}\right)\right\}\left\{\mathrm{LiP}(\mathrm{H})\left(2,4,6-t \mathrm{Bu}_{3} \mathrm{C}_{6} \mathrm{H}_{2}\right)\right\}\right]_{2}[42]\left(\eta_{6}\right.$ fashion) and $\left\{\left[\mathrm{Ar}^{\mathrm{Mes} 2} \mathrm{P}(\mathrm{Ph})\right] \mathrm{Li}(\mathrm{THF})_{2}\right\}\left(\eta_{2}\right.$ fashion) [43], was present (Figure 2).

Due to the sterically demand of the biphenyl ligands, the central $\mathrm{Li}_{2} \mathrm{P}_{2}$ ring appeared to be peripherally shielded and hinders the formation of amorphous polymeric structures. Hence, this allowed the isolation of the dimer. The dimeric motif is common for certain organolithium structures (e.g., see ortho-tolyllithium and para-tolyllithium) [44]. However, it should be highlighted that this crystal structure is one of the rare examples of a phosphide where the metal is not coordinated by any nitrogen or oxygen. For such an example including a planar $\mathrm{P}_{2} \mathrm{Li}_{2}$ ring, the lithium bis(trimethylsilyl)phosphide THF adduct $\left\{\mathrm{Li}\left[\mathrm{P}\left(\mathrm{SiMe}_{3}\right)_{2}\right]_{2} \mathrm{THF}_{2}\right\}_{2}$ [45] and lithium diphenyl phosphide TMEDA adduct $\left(\mathrm{TMEDA} \cdot \mathrm{LiPPh}_{2}\right)_{2}$ are reported. In addition, in the latter structure, both the $\mathrm{P}$ and $\mathrm{Li}$ atoms are found in less distorted tetrahedral environments (mean angles: $\angle(\mathrm{P}-\mathrm{Li}-\mathrm{P})=91^{\circ}$ and 
$\left.\angle(\mathrm{Li}-\mathrm{P}-\mathrm{Li})=89^{\circ}\right)$ with a mean Li-P distance of $2.61 \AA$ [46], or with larger distortion of the $\mathrm{P}_{2} \mathrm{Li}_{2}$ ring in $\left\{\mathrm{Li}\left[\mathrm{P}\left(\mathrm{SiMe}_{3}\right)_{2}\right]_{2} \mathrm{THF}_{2}\right\}_{2}\left(\angle(\mathrm{P}-\mathrm{Li}-\mathrm{P})=100.0(8)^{\circ}, \angle(\mathrm{Li}-\mathrm{P}-\mathrm{Li})=80.0(7)^{\circ}\right)[45]$.

Overall, the close interaction of the biphenyl ligands with the lithium atoms might explain the high stability of the phosphides in solid and solution. This was in good agreement with the observation that the phosphide decomposed as it was mixed with coordinating solvents (THF, diethyl ether).

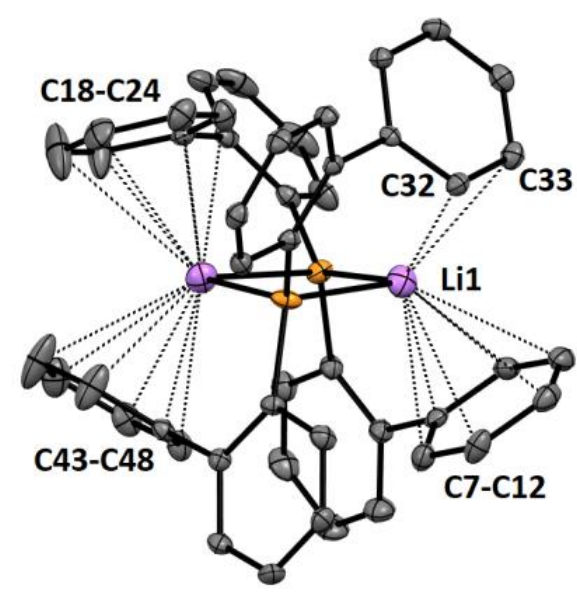

\begin{tabular}{cc}
\hline Connection & Li-C distance \\
\hline Li1-C12 & $2.673(3) \AA$ \\
Li1-C7 & $2.663(3) \AA$ \\
Li1-C33 & $2.852(3) \AA$ \\
$\mathrm{Li} 1-\mathrm{C} 32$ & $2.567(3) \AA$ \\
$\mathrm{Li} 2-\mathrm{C} 19$ & $2.714(3) \AA$ \\
$\mathrm{Li} 2-\mathrm{C} 20$ & $2.672(3) \AA$ \\
$\mathrm{Li} 2-\mathrm{C} 43$ & $2.694(3) \AA$ \\
$\mathrm{Li} 2-\mathrm{C} 48$ & $2.793(3) \AA$ \\
\hline
\end{tabular}

Figure 2. Overview of isolated crystal structure of the phosphide $\mathbf{E}$ and close contacts of the lithium atom with various carbon atoms. The hydrogen atoms were omitted for clarity. Inset: Close lithiumcarbon distances which indicate non-bonding interactions.

\section{Discussion}

The preparation of the bis(biphenyl)phosphide is commonly performed by a one-pot reaction sequence forming the bis(biphenyl)phosphine amide, in-situ formation of the respective chlorophosphine followed by the reduction with elemental lithium [29]. We found that this methodology suffers from the cleavage of any C-P bond due to the use of the strong reductant lithium. Therefore, we report a high yielding process to synthesize the bis(biphenyl)phosphide motif. It uses a step-wise synthetic route from the synthesis of the isolatable bis(biphenyl)phosphine amide, the respective chlorophosphine, phosphine and after subsequent lithiation, finally the phosphide species. Moreover, we examined the phosphides' reactivity with two trimethyltetrel $(\mathrm{Si} / \mathrm{Sn})$ chlorides. As the respective phosphine-trimethyltetrel species could be only accessed for the rather small trimethylsilyl chloride, we conclude that both biphenyls sterically shield the phosphide (see crystal structure) which renders it inaccessible for a reaction with the rather large trimethyltin chloride. This is in contrast to the reactivity of the diphenylphosphide which reacts which trimethyltin chloride [47].

\section{Materials and Methods}

In general, NMR-tubes and glassware were dried in an oven at $200{ }^{\circ} \mathrm{C}$ overnight before use. If not stated otherwise, all reaction vessels were heated to minimum of $200{ }^{\circ} \mathrm{C}$ under vacuum $\left(1.3 \times 10^{-2}\right.$ mbar to $6.2 \times 10^{-2}$ mbar $)$ and purged with argon at least three times before adding reagents. Syringes were purged with argon three times prior use. In general, a nitrogen filled glovebox (Inert Innovative Technology Inc., Newburyport, MA, USA) $\left(<0.1 \mathrm{ppm} \mathrm{O}_{2}\right.$ and $<0.1 \mathrm{ppm}_{2} \mathrm{O}$ ) was used unless noted otherwise. All dry solvents were taken from the solvent purification system (SPS, Inert Technology or MB-SPS-800, M. Braun Inertgas-Systeme $\mathrm{GmbH}$, Garching, Germany), degassed by three freeze-pumpthaw cycles and stored under a nitrogen or argon atmosphere unless noted otherwise. Kugelrohr distillation was performed with a Büchi B-585 Kugelrohr oven (Büchi, Flawil, Switzerland). All NMR -spectra were carried out at 23 C. ${ }^{1} \mathrm{H}$ NMR $(601 \mathrm{MHz})$ and ${ }^{13} \mathrm{C}\left\{{ }^{1} \mathrm{H}\right\}$ NMR (151 MHz) spectra were recorded on a Bruker Avance Neo spectrometer equipped with a TXI probe head. ${ }^{1} \mathrm{H}$ NMR $(601 \mathrm{MHz}),{ }^{13} \mathrm{C}\left\{{ }^{1} \mathrm{H}\right\} \mathrm{NMR}(151 \mathrm{MHz}),{ }^{11} \mathrm{~B}\left\{{ }^{1} \mathrm{H}\right\} \mathrm{NMR}$ 
(193 MHz), ${ }^{29} \mathrm{Si}\left\{{ }^{1} \mathrm{H}\right\}$ NMR (119 MHz) ${ }^{31} \mathrm{P}\left\{{ }^{1} \mathrm{H}\right\}$ NMR $(243 \mathrm{MHz}),{ }^{119} \mathrm{Sn}\left\{\left\{{ }^{1} \mathrm{H}\right\} \mathrm{NMR}(223 \mathrm{MHz})\right.$ spectra were recorded on a Bruker Avance Neo spectrometer equipped with a BBO probe head. ${ }^{1} \mathrm{H},{ }^{13} \mathrm{C},{ }^{29} \mathrm{Si},{ }^{31} \mathrm{P} \mathrm{NMR},{ }^{119} \mathrm{Sn} \mathrm{NMR}$ spectra are reported on the $\delta$ scale $(\mathrm{ppm})$ and are referenced against tetramethylsilane respectively Where possible, NMR signals were assigned using ${ }^{1} \mathrm{H}$ COSY, ${ }^{1} \mathrm{H} /{ }^{1} \mathrm{H}$ NOESY, ${ }^{1} \mathrm{H} /{ }^{13} \mathrm{C}$ HSQC and ${ }^{1} \mathrm{H} /{ }^{13} \mathrm{C} \mathrm{HMBC}$ experiments IR spectra were recorded on a Nicolet Thermo iS10 scientific spectrometer (Thermo Fisher SCIENTIFIC, Waltham, MA, USA) with a diamond ATR unit. Electron impact (EI) mass experiments were measured using the direct inlet or indirect inlet methods on a MAT95 XL double-focusing mass spectrometer from Finnigan MAT (Thermo Fisher SCIENTIFIC, Waltham, MA, USA). The ionization energy of the electron impact ionization was $70 \mathrm{eV}$. Atmospheric pressure chemical ionization (APCI) and electron spray ionization (ESI) experiments were performed on a Bruker Impact II (Bruker Daltonics, Bremen, Germany). Melting points of solids were measured on a Büchi M-5600 Melting Point (Büchi, Flawil, Switzerland) apparatus and are uncorrected.

X-ray measurements were carried out at $100 \mathrm{~K}$ on a Bruker Venture D8 diffractometer (Bruker, Karlsruhe, Germany) with Mo-K $\alpha(0.7107 \AA)$ radiation. Air and moisture sensitive compounds were transferred in the glovebox into a cryoproctectant and then mounted on the diffractometer. All structures were solved by intrinsic phasing and refined based on $\mathrm{F}^{2}$ by use of the SHELX program package, as implemented in Olex2 1.2 [48]. All non-hydrogen atoms were refined using anisotropic displacement parameters. Hydrogen atoms attached to carbon atoms were included in geometrically calculated positions using a riding model. Figures were created using Mercury 4.2. [49].

Commercially available compounds were bought from the subsequent suppliers: 2biphenylmagnesium bromide $\left(0.5 \mathrm{M}_{\text {in }} \mathrm{Et}_{2} \mathrm{O}\right.$, Sigma Aldrich Chemie $\mathrm{GmbH}$, Taufkirchen, Germany), borane THF adduct (1.0 M in THF, Sigma Aldrich), nBuLi (2.5 M in hexanes, Sigma Aldrich Chemie GmbH, Taufkirchen, Germany), (dimethylamino)trimethyltin (>90\%, Sigma Aldrich Chemie GmbH, Taufkirchen, Germany), trimethylsilyl chloride (Sigma Aldrich Chemie GmbH, Taufkirchen, Germany), lithium borohydride (>95\%, Sigma Aldrich), lithium aluminum hydride (1.0 M in THF, Sigma Aldrich Chemie GmbH, Taufkirchen, Germany), hydrogen chloride (2.0 M in $\mathrm{Et}_{2} \mathrm{O}$, Sigma Aldrich Chemie GmbH, Taufkirchen, Germany).

The amino-protected dichlorophosphine A was synthesized by the reaction of phosphorus trichloride and two equivalents of diisopropylamine according to a literature protocol [50].

bis(Biphenyl-2-yl)-N,N-diisopropylphosphanamine (B)

Under constant stirring at $0^{\circ} \mathrm{C}$ 2-biphenylmagensium bromide $(30.0 \mathrm{~mL}, 15.0 \mathrm{mmol}$, $0.5 \mathrm{M}$ in diethyl ether) was added to $n$-pentane $(100 \mathrm{~mL})$. To this $\mathbf{A}(1.30 \mathrm{~mL}, 7.07 \mathrm{mmol})$ was added dropwise and the solution formed a white precipitate. The reaction progress was followed by ${ }^{31} \mathrm{P}$ NMR spectroscopy. After $14 \mathrm{~h}$ of stirring at $25^{\circ} \mathrm{C}$, the solids were filtrated off and washed with $n$-pentane $(100 \mathrm{~mL})$. All volatiles were removed at reduced pressure and recrystallization of the solid was performed by dissolving the residue in a minimal amount of DCM and adding acetonitrile $(100 \mathrm{~mL})$ in an open flask. Using fractional crystallization, the product was obtained in high purity as colorless crystals (B, $3.02 \mathrm{~g}, 6.91 \mathrm{mmol}, 97 \%)$, which were also suitable for X-ray analysis. ${ }^{1} \mathbf{H} \mathbf{~ N M R}(601 \mathrm{MHz}$, DCM- $\left.d_{2}\right): \delta=7.42\left(\mathrm{dd},{ }^{3} J=7.4 \mathrm{~Hz},{ }^{4} J=1.5 \mathrm{~Hz}, 2 \mathrm{H}, H-3\right), 7.31\left(\mathrm{td},{ }^{3} J=7.4,{ }^{4} J=1.5 \mathrm{~Hz}, 2 \mathrm{H}\right.$, $H-5), 7.27\left(\mathrm{td},{ }^{3} J=7.4 \mathrm{~Hz},{ }^{4} J=1.5 \mathrm{~Hz}, 2 \mathrm{H}, \mathrm{H}-4\right), 7.25-7.18(\mathrm{~m}, 6 \mathrm{H}, H-9,10,11), 7.06\left(\mathrm{ddd},{ }^{3} J=\right.$ $\left.7.4{ }^{3} \mathrm{~J}=4.7,{ }^{4} \mathrm{~J}=1.5 \mathrm{~Hz}, 2 \mathrm{H}, \mathrm{H}-6\right), 7.04\left(\mathrm{~d},{ }^{3} \mathrm{~J}=7.5 \mathrm{~Hz}, 4 \mathrm{H}, \mathrm{H}-8,12\right), 3.24-3.13$ (two hept., ${ }^{3} \mathrm{~J}=$ $6.7 \mathrm{~Hz}, 2 \mathrm{H}, \mathrm{CH}), 0.68\left(\mathrm{~d},{ }^{3} \mathrm{~J}=6.7 \mathrm{~Hz}, 12 \mathrm{H}, \mathrm{CH}_{3}\right)$ ppm. ${ }^{13} \mathrm{C}\left\{{ }^{1} \mathbf{H}\right\} \mathbf{N M R}\left(151 \mathrm{MHz}, \mathrm{DCM}-d_{2}\right)$ : $\delta=146.79\left(\mathrm{~d},{ }^{2} J_{\mathrm{C}-\mathrm{P}}=27.8 \mathrm{~Hz}, \mathrm{C}-1\right), 142.78\left(\mathrm{~d},{ }^{3} J_{\mathrm{C}-\mathrm{P}}=4.2 \mathrm{~Hz}, \mathrm{C}-7\right), 139.98\left(\mathrm{~d},{ }^{1} J_{\mathrm{C}-\mathrm{P}}=20.0 \mathrm{~Hz}\right.$, C-2), 133.81 (s (br), C-3), 130.73 (d, $\left.{ }^{4} J_{C-P}=4.3 \mathrm{~Hz}, C-8,12\right), 130.61$ (d, $\left.{ }^{3} J_{C-P}=3.4 \mathrm{~Hz}, C-6\right)$, 128.43 (s, C-5), 127.89 (s, C-9,10,11), 127.66 (d, $\left.{ }^{3} J_{\mathrm{C}-\mathrm{P}}=5.0 \mathrm{~Hz}, \mathrm{C}-4\right), 47.74$ (s (br), CH), 23.50 (s, $\left.\mathrm{CH}_{3}\right)$ ppm. ${ }^{31} \mathbf{P}\left\{{ }^{1} \mathbf{H}\right\}$ NMR $\left(243 \mathrm{MHz}, \mathrm{DCM}-d_{2}\right): \delta=22.52$ (s) ppm. IR (ATR): $v=3053(\mathrm{w})$, $2964(w), 2925(w), 1456(w), 1443(w), 1424(w), 1386(w), 1360(w), 1191$ (w), 1174 (w), 1118 (m), 1071 (s), 1008 (w), 962 (m), 912 (w), 775 (w), 744 (s), 698 (s) cm ${ }^{-1}$. HRMS (EI, 
$70 \mathrm{eV}$, MAT95, direct): $m / z$ [M-H] ${ }^{+}$Calcd. for $\mathrm{C}_{30} \mathrm{H}_{31} \mathrm{NP}$ 436.21886; Found 436.21914; $[\mathrm{M}]^{+\cdot}$ Calcd. for $\mathrm{C}_{30} \mathrm{H}_{32} \mathrm{NP}$ 437.22669; Found 437.22676: MS (EI): $m / z$ 437.3 (35\%) [M] ${ }^{+\cdot}$, $337.2(49 \%)\left[\mathrm{M}-\mathrm{N}(\mathrm{iPr})_{2}\right]^{+} \cdot, 183.0(100 \%)\left[\mathrm{M}-\mathrm{H},\left(\mathrm{N}(\mathrm{iPr})_{2}\right),\left(\mathrm{C}_{12} \mathrm{H}_{9}\right)\right]^{+} . \mathbf{M p}: 125^{\circ} \mathrm{C}$.

Single crystals were obtained by slow evaporation of an ACN/DCM mixture at $25{ }^{\circ} \mathrm{C}$. Crystal Data for $\mathrm{C}_{30} \mathrm{H}_{32} \mathrm{NP}(\mathrm{M}=437.57 \mathrm{~g} / \mathrm{mol})$ : triclinic, space group $\mathrm{P}-1, \mathrm{a}=9.4189(3)$ $\AA, b=11.1819(4) \AA, c=12.7140(4) \AA, \alpha=89.0990(10)^{\circ}, \beta=76.1210(10)^{\circ}, \gamma=70.6150(10)^{\circ}$, $\mathrm{V}=1223.28(7) \AA^{3}, \mathrm{Z}=2, \mathrm{~T}=100.0 \mathrm{~K}, \mu(\mathrm{MoK} \alpha)=0.130 \mathrm{~mm}^{-1}, \mathrm{D}_{\text {calc }}=1.188 \mathrm{~g} / \mathrm{cm}^{3}, 102866$ reflections measured $\left(5.472^{\circ} \leq 2 \Theta \leq 66.998^{\circ}\right), 9585$ unique $\left(R_{\text {int }}=0.0282, R_{\text {sigma }}=0.0149\right)$, which were used in all calculations. The final $R_{1}$ was $0.0333(\mathrm{I}>2 \sigma(\mathrm{I}))$ and $w \mathrm{R}_{2}$ was 0.0960 (all data).

bis(Biphenyl-2-yl)chlorophosphine (C)

In a Schlenk flask, B $(1.00 \mathrm{~g}, 2.28 \mathrm{mmol})$ was dissolved in diethyl ether $(60 \mathrm{~mL})$. To this a hydrogen chloride solution $(8.00 \mathrm{~mL}, 16.0 \mathrm{mmol}, 2.0 \mathrm{M}$ in diethyl ether) was added. The reaction mixture turned directly cloudy and was stirred for $2 \mathrm{~h}$ while the reaction progress was monitored by ${ }^{31} \mathrm{P}$ NMR. The reaction mixture was allowed to settle and afterwards transferred into another Schlenk flask using syringe filters. A yellow oil was received after drying $\left(25^{\circ} \mathrm{C}, 2.2 \times 10^{-2} \mathrm{mbar}\right)$ and used for further steps. For analytical purposes, a part of the reaction mixture $(247 \mathrm{mg}, 0.67 \mathrm{mmol})$ was distilled by inert fractional Kugelrohr distillation $\left(180{ }^{\circ} \mathrm{C}, 3.2 \times 10^{-2}\right.$ mbar $)$ to give the crystalline product $(\mathbf{D}, 86 \mathrm{mg}, 0.23 \mathrm{mmol}$, $34 \%$ ). Crystals which were suitable for X-ray analysis could be directly taken from the solidified distillate. Due to the high temperature in this process, also oxidation products (phosphinic chloride $\left({ }^{31} \mathrm{P}\right.$ NMR $\left.\delta=34.0 \mathrm{ppm}\right)$ and phosphine oxides $\left({ }^{31} \mathrm{P}\right.$ NMR $\delta=15.9$ $\left.\left.\left({ }^{1} J_{\mathrm{PH}}=503.3 \mathrm{~Hz}\right) \mathrm{ppm}\right)\right)$ were detectable after distillation. ${ }^{1} \mathbf{H} \mathbf{~ N M R}\left(601 \mathrm{MHz}, \mathrm{CDCl}_{3}\right): \delta$ $=7.72(\mathrm{~m}, 2 \mathrm{H}, \mathrm{H}-3), 7.48-7.40(\mathrm{~m}, 4 \mathrm{H}, \mathrm{H}-5$ and $\mathrm{H}-4), 7.35-7.30(\mathrm{~m}, 2 \mathrm{H}, \mathrm{H}-10), 7.26\left(\mathrm{t},{ }^{3} \mathrm{~J}=\right.$ $7.6 \mathrm{~Hz}, 4 \mathrm{H}, \mathrm{H}-9,11), 7.22-7.19(\mathrm{~m}, 2 \mathrm{H}, \mathrm{H}-6), 6.99\left(\mathrm{~d},{ }^{3} \mathrm{~J}=7.6 \mathrm{~Hz}, 4 \mathrm{H}, \mathrm{H}-8,12\right) \mathrm{ppm} .{ }^{13} \mathrm{C}\left\{{ }^{1} \mathbf{H}\right\}$ NMR (151 MHz, CDCl 3 ): $\delta=146.79\left(\mathrm{~d},{ }^{2} J_{\mathrm{C}-\mathrm{P}}=32.4 \mathrm{~Hz}, \mathrm{C}-1\right), 140.31\left(\mathrm{~d},{ }^{3} J_{\mathrm{C}-\mathrm{P}}=6.6 \mathrm{~Hz}, \mathrm{C}-7\right)$, $137.03\left(\mathrm{~d},{ }^{1} J_{\mathrm{C}-\mathrm{P}}=38.9 \mathrm{~Hz}, \mathrm{C}-2\right), 132.52\left(\mathrm{~d},{ }^{2} J_{\mathrm{C}-\mathrm{P}}=2.1 \mathrm{~Hz}, \mathrm{C}-3\right), 130.06(\mathrm{~s}, \mathrm{C}-5), 130.01\left(\mathrm{~d},{ }^{3} J_{\mathrm{C}-\mathrm{P}}\right.$ = $3.4 \mathrm{~Hz}, \mathrm{C}-6), 129.74\left(\mathrm{~d},{ }^{4} J_{\mathrm{C}-\mathrm{P}}=4.9 \mathrm{~Hz}, \mathrm{C}-8,12\right), 127.96$ (s, C-9,11), 127.78 (s, C-4), 127.55 (s, C-10) ppm. ${ }^{31} \mathbf{P}\left\{{ }^{1} \mathbf{H}\right\}$ NMR (243 $\left.\mathrm{MHz} \mathrm{CDCl}_{3}\right): \delta=74.53$ (s) ppm. HRMS (EI, 70 eV, MAT95, direct): $m / z$ [M-H] $]^{+}$Calcd. for $\mathrm{C}_{24} \mathrm{H}_{17} \mathrm{PCl} 371.07509$; Found 371.07512; [M-H,HCl] ${ }^{+\cdot}$ Calcd. for $\mathrm{C}_{24} \mathrm{H}_{16} \mathrm{P}$ 335.09841; Found 355.09838. MS (EI): $m / z 371.2$ (100\%) [M-H] $]^{+}, 335.2$ (27\%) $\left.[\mathrm{M}-\mathrm{H}, \mathrm{HCl}]^{+}, 183.0(60 \%)[\mathrm{M}-\mathrm{H}, \mathrm{HCl}),\left(\mathrm{C}_{12} \mathrm{H}_{9}\right)\right]^{+}$.

bis(Biphenyl-2-yl)phosphine (D)

To a solution of freshly prepared C $(0.32 \mathrm{mmol})$ in THF $(40 \mathrm{~mL})$, lithium aluminum hydride solution $\left(0.32 \mathrm{~mL}, 0.32 \mathrm{mmol}, 1.0 \mathrm{M}\right.$ in THF) was added at $25^{\circ} \mathrm{C}$. The reaction mixture was stirred for $15 \mathrm{~h}$ and the reaction progress was observed via ${ }^{31} \mathrm{P} \mathrm{NMR}$. After completion of the reaction the solvent was removed in vacuo and the residue was dissolved in toluene $(2.0 \mathrm{~mL})$ and filtered over Celite. The product was obtained using inert Kugelrohr distillation $\left(130-160{ }^{\circ} \mathrm{C}, 2.0 \times 10^{-3} \mathrm{mbar}\right)$ and the product was isolated as colorless solid (D, $99 \mathrm{mg}, 0.29 \mathrm{mmol}, 91 \%$ ). Crystals which were suitable for X-ray analysis were obtained after solidification of the distillate. ${ }^{1} \mathrm{H}$ NMR $\left(601 \mathrm{MHz}, \mathrm{C}_{6} \mathrm{D}_{6}\right): \delta=7.32\left(\mathrm{ddd},{ }^{3} J=7.4\right.$, $\left.5.7 \mathrm{~Hz},{ }^{4} \mathrm{~J}=0.9 \mathrm{~Hz}, 2 \mathrm{H}, \mathrm{H}-3\right), 7.18(\mathrm{~m}, 4 \mathrm{H}, \mathrm{H}-8,12), 7.16-7.12(\mathrm{~m}, 2 \mathrm{H}, \mathrm{H}-6), 7.09-7.03(\mathrm{~m}, 4 \mathrm{H}$, $H-5, H-9,11$ and $H-10), 7.06\left(\mathrm{tt}^{3} \mathrm{~J}=7.5 \mathrm{~Hz},{ }^{4} \mathrm{~J}=1.1 \mathrm{~Hz}, 2 \mathrm{H}, \mathrm{H}-4\right), 4.97\left(\mathrm{~d},{ }^{1} J_{\mathrm{P}-\mathrm{H}}=223.0 \mathrm{~Hz}\right.$, $1 \mathrm{H}, \mathrm{PH})$ ppm. ${ }^{13} \mathrm{C}\left\{{ }^{1} \mathrm{H}\right\}$ NMR $\left(151 \mathrm{MHz}, \mathrm{C}_{6} \mathrm{D}_{6}\right): \delta=147.18\left(\mathrm{~d},{ }^{2} J_{\mathrm{C}-\mathrm{P}}=16.4 \mathrm{~Hz}, \mathrm{C}-1\right), 142.10$ $\left(\mathrm{d},{ }^{3} J_{\mathrm{C}-\mathrm{P}}=3.3 \mathrm{~Hz}, \mathrm{C}-7\right), 135.55\left(\mathrm{~d},{ }^{1} J_{\mathrm{C}-\mathrm{P}}=10.1 \mathrm{~Hz}, \mathrm{C}-3\right), 134.24\left(\mathrm{~d},{ }^{2} J_{\mathrm{C}-\mathrm{P}}=15.9 \mathrm{~Hz}, \mathrm{C}-2\right)$, $129.91\left(\mathrm{~d},{ }^{3} J_{\mathrm{C}-\mathrm{P}}=2.7 \mathrm{~Hz}, \mathrm{C}-6\right), 129.91\left(\mathrm{~d},{ }^{3} J_{\mathrm{C}-\mathrm{P}}=3.1 \mathrm{~Hz}, \mathrm{C}-8,12\right), 128.27$ (s, C-5), 127.85 (overlapping with $\mathrm{C}_{6} \mathrm{D}_{6}$ signal, $\mathrm{C}-9,11,129.74\left(\mathrm{~d},{ }^{4} J_{\mathrm{C}-\mathrm{P}}=3.4 \mathrm{~Hz}, \mathrm{C}-4\right), 127.05$ (s, C-10) ppm. ${ }^{31} \mathbf{P}\left\{{ }^{1} \mathbf{H}\right\}$ NMR $\left(243 \mathrm{MHz}, \mathrm{CDCl}_{3}\right): \delta=-53.87$ (s) ppm. ${ }^{31} \mathbf{P} \mathbf{N M R}\left(243 \mathrm{MHz}, \mathrm{CDCl}_{3}\right): \delta=$ $-53.87\left(\mathrm{~d},{ }^{1} J_{\mathrm{P}-\mathrm{H}}=223.0 \mathrm{~Hz}\right)$ ppm. HRMS (EI, $70 \mathrm{eV}$, MAT95, direct): $\mathrm{m} / z[\mathrm{M}-\mathrm{H}]^{+}$Calcd. for $\mathrm{C}_{24} \mathrm{H}_{18} \mathrm{P}$ 337.11406; Found 337.11412. MS (EI, $\left.120^{\circ} \mathrm{C}\right): \mathrm{m} / z 337.1(80 \%)[\mathrm{M}-\mathrm{H}]^{+}, 335.2$ (27\%) [M], $\left.183.0(100 \%)[\mathrm{M}-\mathrm{H}),\left(\mathrm{C}_{12} \mathrm{H}_{9}\right)\right]^{+}$.

Crystal Data for $\mathrm{C}_{24} \mathrm{H}_{19} \mathrm{P}(\mathrm{M}=338.36 \mathrm{~g} / \mathrm{mol})$ : monoclinic, space group $\mathrm{P} 21 / \mathrm{c}$ (no. 14), $\mathrm{a}=7.5529(2) \AA, \mathrm{b}=20.0280(6) \AA, c=11.7785(3) \AA, \beta=94.2750(10)^{\circ}, \mathrm{V}=1776.77(8) \AA^{3}$, $\mathrm{Z}=4, \mathrm{~T}=100.0 \mathrm{~K}, \mu(\mathrm{MoK} \alpha)=0.157 \mathrm{~mm}^{-1}, \mathrm{D}_{\text {calc }}=1.265 \mathrm{~g} / \mathrm{cm}^{3}, 36505$ reflections measured 
$\left(5.346^{\circ} \leq 2 \Theta \leq 57^{\circ}\right), 4485$ unique $\left(R_{\text {int }}=0.0402, R_{\text {sigma }}=0.0225\right)$, which were used in all calculations. The final $R_{1}$ was $0.0389(\mathrm{I}>2 \sigma(\mathrm{I}))$ and $\mathrm{wR}_{2}$ was 0.0912 (all data).

bis(Biphenyl-2-yl)phosphine borane (F)

Method A: In a Schlenk flask, D $(169 \mathrm{mg}, 0.50 \mathrm{mmol})$ was dissolved in THF $(20 \mathrm{~mL})$. To this the borane solution $(0.50 \mathrm{~mL}, 0.50 \mathrm{mmol}, 1.0 \mathrm{M}$ in THF) was slowly added. The reaction was stirred at $50{ }^{\circ} \mathrm{C}$ for $2 \mathrm{~h}$. After removal of the solvent the residue was mixed with $n$-hexane $(20 \mathrm{~mL})$ and stirred for $30 \mathrm{~min}$. Afterwards, the white cloudy solution was allowed so settle for $14 \mathrm{~h}$. The supernatant was transferred through syringe filters into a another Schlenk flask. The flask was stored at $-8{ }^{\circ} \mathrm{C}$ giving a cloudy color to the glass surface. After 6 days the solution was decanted, and the white solids were collected. The recrystallization from $n$-hexane $(50 \mathrm{~mL})$ gave colorless crystals $(\mathbf{F}, 85 \mathrm{mg}, 0.24 \mathrm{mmol}, 48 \%)$. These crystals were suitable for X-Ray analysis.

Method B: To a solution of $\mathrm{LiBH}_{4}(6.5 \mathrm{mg}, 0.30 \mathrm{mmol})$ in diethyl ether $(5.0 \mathrm{~mL})$, a solution of $\mathbf{C}(49.4 \mathrm{mg}, 0.131 \mathrm{mmol})$ in THF $(5.0 \mathrm{~mL})$ was added dropwise at $0{ }^{\circ} \mathrm{C}$. Reaction progress was monitored with ${ }^{31} \mathrm{P}$ NMR and visible signals for the product were recognized. After $1 \mathrm{~h}$ of stirring at $25^{\circ} \mathrm{C}$, the solvent was removed, and the reaction mixture was dissolved in $n$-hexane $(10 \mathrm{~mL})$ at $60{ }^{\circ} \mathrm{C}$. This solution was transferred through syringe filters into another Schlenk flask and stored in a freezer $\left(-30^{\circ} \mathrm{C}\right)$ in the glove box to obtain colorless crystals (F, $44 \mathrm{mg}, 0.125 \mathrm{mmol}, 94 \%) .{ }^{1} \mathbf{H}$ NMR $\left(601 \mathrm{MHz}, \mathrm{C}_{6} \mathrm{D}_{6}\right): \delta=7.89\left(\mathrm{dd},{ }^{3} \mathrm{~J}=\right.$ $12.8,7.6 \mathrm{~Hz}, 2 \mathrm{H}, \mathrm{H}-3), 7.12-6.98(\mathrm{~m}, 10 \mathrm{H}, \mathrm{H}-4,5$ and $H-9,10,11), 6.95\left(\mathrm{dd},{ }^{3} \mathrm{~J}=7.6,{ }^{4} \mathrm{~J}=3.3 \mathrm{~Hz}\right.$, $2 \mathrm{H}, H-6), 6.84(\mathrm{~s}(\mathrm{br}), 4 \mathrm{H}, \mathrm{H}-8,12), 6.30\left(\mathrm{dq},{ }^{1} J_{\mathrm{P}-\mathrm{H}}=396.4 \mathrm{~Hz},{ }^{2} J_{\mathrm{PH}-\mathrm{BH} 3}=6.7 \mathrm{~Hz}, 1 \mathrm{H}, \mathrm{PH}\right), 2.13$ $\left(\mathrm{d},{ }^{1} J_{\mathrm{BH}}=126.9 \mathrm{~Hz}, 3 \mathrm{H}, \mathrm{BH} / \mathrm{p}_{3} \mathrm{ppm} .{ }^{13} \mathrm{C}\left\{{ }^{1} \mathbf{H}\right\} \mathbf{N M R}\left(151 \mathrm{MHz}, \mathrm{C}_{6} \mathrm{D}_{6}\right): \delta=146.79\left(\mathrm{~d},{ }^{2} J_{\mathrm{C}-\mathrm{P}}=\right.\right.$ $2.8 \mathrm{~Hz}, \mathrm{C}-1), 140.21\left(\mathrm{~d},{ }^{3} J_{\mathrm{C}-\mathrm{P}}=3.6 \mathrm{~Hz}, \mathrm{C}-7\right), 134.51\left(\mathrm{~d},{ }^{3} J_{\mathrm{C}-\mathrm{P}}=15.2 \mathrm{~Hz}, \mathrm{C}-3\right), 130.87\left(\mathrm{~d},{ }^{4} J_{\mathrm{C}-\mathrm{P}}=\right.$ $2.4 \mathrm{~Hz}, \mathrm{C}-5), 130.53\left(\mathrm{~d},{ }^{3} J_{\mathrm{C}-\mathrm{P}}=6.2 \mathrm{~Hz}, \mathrm{C}-6\right), 129.35$ (s, C-8,12), 128.21 (overlap with benzene, C-9,11), 127.72 (s, C-10), 127.66 (within $\left.{ }^{3} J_{C-P}=11.8 \mathrm{~Hz}, C-4\right), 126.96$ (d, $\left.{ }^{1} J_{C-P}=54.5 \mathrm{~Hz}, C-2\right)$ ppm. ${ }^{11} \mathbf{B}\left\{{ }^{1} \mathbf{H}\right\}$ NMR $\left(193 \mathrm{MHz}, \mathrm{C}_{6} \mathrm{D}_{6}\right): \delta=-36.69$ (s, br) ppm. ${ }^{11} \mathbf{B} \mathbf{N M R}\left(193 \mathrm{MHz}, \mathrm{C}_{6} \mathrm{D}_{6}\right)$ : $\delta=-36.69\left(\mathrm{~d},{ }^{1} J_{\mathrm{B}-\mathrm{H}}=52.7 \mathrm{~Hz}\right) \mathrm{ppm} .{ }^{31} \mathbf{P}\left\{{ }^{1} \mathrm{H}\right\} \mathbf{N M R}\left(243 \mathrm{MHz}, \mathrm{C}_{6} \mathrm{D}_{6}\right): \delta=-14.09(\mathrm{~s}) \mathrm{ppm}$. ${ }^{31} \mathbf{P}$ NMR $\left(243 \mathrm{MHz}, \mathrm{C}_{6} \mathrm{D}_{6}\right): \delta=-14.09\left(\mathrm{~d},{ }^{1} J_{\mathrm{P}-\mathrm{H}}=397.9 \mathrm{~Hz}\right) \mathrm{ppm}$. HRMS (ESI, Impact II, DCM/acetonitrile): $m / z[\mathrm{M}+\mathrm{K}]^{+}$Calcd. for $\mathrm{C}_{24} \mathrm{H}_{22} \mathrm{PBK}$ 391.11838; Found 391.11864, $\left[\left(\mathrm{M}_{-} \mathrm{BH}_{3}\right)+\mathrm{K}\right]^{+}$Calcd. for $\mathrm{C}_{24} \mathrm{H}_{18} \mathrm{PK}$ 377.08560; Found 377.08567, $[\mathrm{M}+\mathrm{Na}]^{+}$Calcd. for $\mathrm{C}_{24} \mathrm{H}_{22} \mathrm{PBNa} 375.14444$; Found 375.14472, $\left[\left(\mathrm{M}-\mathrm{BH}_{3}\right)+\mathrm{Na}\right]^{+}$Calcd. for $\mathrm{C}_{24} \mathrm{H}_{19} \mathrm{PNa} 361.11166$; Found 361.11159.

Single crystals were obtained after cooling a saturated hexane/benzene solution to $-10{ }^{\circ} \mathrm{C}$ for several days. Crystal Data for $\mathrm{C}_{24} \mathrm{H}_{22} \mathrm{BP}\left(\mathrm{C}_{6} \mathrm{H}_{6}\right)_{0.5}(\mathrm{M}=391.25 \mathrm{~g} / \mathrm{mol})$ : monoclinic, space group P2 $1 / \mathrm{c}, \mathrm{a}=11.8705(5) \AA, \mathrm{b}=10.2205(4) \AA, c=17.8670(7) \AA, \beta$ $=93.7090(10)^{\circ}, \mathrm{V}=2163.13(15) \AA^{3}, \mathrm{Z}=4, \mathrm{~T}=100.0 \mathrm{~K}, \mu(\mathrm{MoK} \alpha)=0.137 \mathrm{~mm}^{-1}, \mathrm{D}_{\text {calc }}$ $=1.201 \mathrm{~g} / \mathrm{cm}^{3}, 78277$ reflections measured $\left(4.594^{\circ} \leq 2 \Theta \leq 59.996^{\circ}\right), 6303$ unique $\left(R_{\text {int }}\right.$ $\left.=0.0291, R_{\text {sigma }}=0.0146\right)$, which were used in all calculations. The final $R_{1}$ was 0.0352 $(\mathrm{I}>2 \sigma(\mathrm{I}))$ and $\mathrm{wR}_{2}$ was 0.0974 (all data).

Lithium bis(biphenyl-2-yl)phosphide (E)

In the glove box, phosphine $\mathbf{D}(20.0 \mathrm{mg}, 59.7 \mu \mathrm{mol})$ was dissolved in benzene $(10 \mathrm{~mL})$ and $n$-butyllithium $(0.50 \mathrm{~mL}, 125 \mu \mathrm{mol}, 2.5 \mathrm{M}$ in hexanes $)$ was added at $25^{\circ} \mathrm{C}$. The reaction mixture was stirred for $2 \mathrm{~h}$ and the supernatant was filtered through syringe filters. The solution was crystallized by over layering the solution with $n$-hexane to give the product as orange solids (E, $19.7 \mathrm{mg}, 58.9 \mu \mathrm{mol}, 99 \%)$. ${ }^{1} \mathbf{H}$ NMR $\left(601 \mathrm{MHz}, \mathrm{C}_{6} \mathrm{D}_{6}\right.$ :THF- $d_{8}$ 80:20): $\delta=$ $7.32\left(\mathrm{dd},{ }^{3} \mathrm{~J}=7.4,5.7 \mathrm{~Hz},{ }^{4} \mathrm{~J}=1.4 \mathrm{~Hz}, 2 \mathrm{H}, \mathrm{H}-3\right), 7.18\left({ }^{3} \mathrm{~J}=7.6 \mathrm{~Hz}, 4 \mathrm{H}, H-8,12\right), 7.09-7.03$ (m, $4 \mathrm{H}, \mathrm{H}-6$ and $H-9,11), 6.98\left(\mathrm{t},{ }^{3} \mathrm{~J}=7.0 \mathrm{~Hz}, 2 \mathrm{H}, \mathrm{H}-4\right), 6.94\left(\mathrm{t},{ }^{3} \mathrm{~J}=7.7 \mathrm{~Hz}, 2 \mathrm{H}, H-10\right), 6.85\left(\mathrm{t},{ }^{3} \mathrm{~J}=\right.$ $7.8 \mathrm{~Hz}, 2 \mathrm{H}, \mathrm{H}-5)$ ppm. ${ }^{13} \mathrm{C}\left\{{ }^{1} \mathbf{H}\right\}$ NMR $\left(151 \mathrm{MHz}, \mathrm{C}_{6} \mathrm{D}_{6}: \mathrm{THF}-d_{8} 80: 20\right): \delta=153.92\left(\mathrm{~d},{ }^{1} J_{\mathrm{C}-\mathrm{P}}=\right.$ $49.6 \mathrm{~Hz}, \mathrm{C}-2), 146.45\left(\mathrm{~d},{ }^{3} J_{\mathrm{C}-\mathrm{P}}=3.1 \mathrm{~Hz}, \mathrm{C}-7\right), 142.10\left(\mathrm{~d},{ }^{3} J_{\mathrm{C}-\mathrm{P}}=20.6 \mathrm{~Hz}, \mathrm{C}-1\right), 135.55(\mathrm{~s}, \mathrm{C}-3)$, $129.67\left(\mathrm{~d},{ }^{3} J_{\mathrm{C}-\mathrm{P}}=5.8 \mathrm{~Hz}, \mathrm{C}-8,12\right), 129.67\left(\mathrm{~d},{ }^{3} J_{\mathrm{C}-\mathrm{P}}=2.1 \mathrm{~Hz}, \mathrm{C}-6\right), 126.96(\mathrm{~s}, \mathrm{C}-9,11), 125.65$ (s, C-10), 125.06 (s, C-4), 120.45 (s, C-5) ppm. ${ }^{9}$ Li NMR (233 MHz, C $6 \mathrm{D}_{6}:$ THF- $d_{8}$ 80:20): $\delta=$ -0.06 (s) ppm. ${ }^{31} \mathbf{P}$ NMR (243 MHz, $\mathrm{C}_{6} \mathrm{D}_{6}: \mathrm{THF}-d_{8}$ 80:20): $\delta=-33.39$ (s) ppm. ${ }^{31} \mathbf{P}$ NMR (243 MHz, $\mathrm{C}_{6} \mathrm{D}_{6}$ ): $\delta=-52.41$ (s) ppm. 
Single crystals were obtained from evaporation of a sat. benzene solution in the glovebox. Crystal Data for $\left(\mathrm{C}_{24} \mathrm{H}_{18} \mathrm{LiP}\right)(\mathrm{M}=344.29 \mathrm{~g} / \mathrm{mol})$ : monoclinic, space group $\mathrm{P} 2{ }_{1} / \mathrm{n}, \mathrm{a}=12.6051(9) \AA, \mathrm{b}=16.0123(12) \AA, \mathrm{c}=18.4340(12) \AA, \beta=104.712(2)^{\circ}, \mathrm{V}=3598.7(4)$ $\AA^{3}, \mathrm{Z}=8, \mathrm{~T}=100.0 \mathrm{~K}, \mu(\mathrm{MoK} \alpha)=0.156 \mathrm{~mm}^{-1}, \mathrm{D}_{\text {calc }}=1.271 \mathrm{~g} / \mathrm{cm}^{3}, 108594$ reflections measured $\left(4.2^{\circ} \leq 2 \Theta \leq 61.016^{\circ}\right), 10966$ unique $\left(R_{\text {int }}=0.0504, R_{\text {sigma }}=0.0288\right)$, which were used in all calculations. The final $\mathrm{R}_{1}$ was 0.0447 (I $>2 \sigma(\mathrm{I})$ ) and $\mathrm{wR}_{2}$ was 0.1170 (all data).

bis(Biphenyl-2-yl)(trimethylsilyl)phosphine (G)

To a solution of $\mathbf{D}(63 \mathrm{mg}, 59.0 \mu \mathrm{mol})$ in benzene $(2.0 \mathrm{~mL}), n$-butyllithium $(47.0 \mu \mathrm{L}$, $118 \mu \mathrm{mol}, 2.5 \mathrm{M}$ in hexanes) was added and the reaction mixture was stirred at $25^{\circ} \mathrm{C}$ for 2 $\mathrm{h}$, giving an intense orange color. To this solution, trimethylsilyl chloride $(100 \mu \mathrm{L}, 786 \mu \mathrm{mol})$ was added in one portion. The reaction mixture was allowed to settle and the supernatant solution was transferred to another flask. After removal of all volatiles and drying $\left(25{ }^{\circ} \mathrm{C}\right.$, $\left.2 \mathrm{~h}, 1 \times 10^{-3} \mathrm{mbar}\right)$, a white waxy solid was obtained (G, $\left.22 \mathrm{mg}, 53.8 \mu \mathrm{mol}, 91 \%\right) .{ }^{1} \mathbf{H}$ NMR (601 MHz, $\left.\mathrm{C}_{6} \mathrm{D}_{6}\right): \delta=7.60-7.57(\mathrm{~m}, 2 \mathrm{H}, H-3), 7.23-7.20(\mathrm{~m}, 4 \mathrm{H}, H-8,12), 7.19-7.16(\mathrm{~m}$, overlapping with residual benzene signals, $2 \mathrm{H}, \mathrm{H}-6), 7.16-7.12(\mathrm{~m}, 4 \mathrm{H}, \mathrm{H}-9,11), 7.11-7.07$ $(\mathrm{m}, 4 \mathrm{H}, H-5$ and $H-10), 7.05\left(\mathrm{td},{ }^{3} J=7.4 \mathrm{~Hz},{ }^{4} J=1.1 \mathrm{~Hz}, 2 \mathrm{H}, H-4\right),-0.03\left(\mathrm{~d},{ }^{3} J_{\mathrm{P}-\mathrm{Si}(\mathrm{CH}) 3}\right.$ $\left.=4.50 \mathrm{~Hz}, 9 \mathrm{H}, \mathrm{CH}_{3}\right) \mathrm{ppm} .{ }^{13} \mathrm{C}\left\{{ }^{1} \mathrm{H}\right\} \mathrm{NMR}\left(151 \mathrm{MHz}, \mathrm{C}_{6} \mathrm{D}_{6}\right): \delta=148.49\left(\mathrm{~d},{ }^{2} J_{\mathrm{C}-\mathrm{P}}=26.0\right.$ $\mathrm{Hz}, \mathrm{C}-1), 143.28\left(\mathrm{~d},{ }^{3} J_{\mathrm{C}-\mathrm{P}}=4.9 \mathrm{~Hz}, \mathrm{C}-7\right), 136.32\left(\mathrm{~d},{ }^{1} J_{\mathrm{C}-\mathrm{P}}=10.1 \mathrm{~Hz}, \mathrm{C}-3\right), 135.82\left(\mathrm{~d},{ }^{2} J_{\mathrm{C}-\mathrm{P}}=\right.$ $21.0 \mathrm{~Hz}, \mathrm{C}-2), 131.31\left(\mathrm{~d},{ }^{3} J_{\mathrm{C}-\mathrm{P}}=4.9 \mathrm{~Hz}, \mathrm{C}-6\right), 130.59\left(\mathrm{~d},{ }^{3} J_{\mathrm{C}-\mathrm{P}}=3.9 \mathrm{~Hz}, \mathrm{C}-8,12\right), 128.35(\mathrm{~s}$, C-10), 127.99 (s, overlapping with $\mathrm{C}_{6} \mathrm{D}_{6}$ signal, $C-9,11$ and $\left.C-5\right), 127.10\left(\mathrm{~d},{ }^{4} J_{\mathrm{C}-\mathrm{P}}=5.3 \mathrm{~Hz}\right.$, C-4 $),-0.48\left(\mathrm{~d},{ }^{2} J_{\mathrm{C}-\mathrm{P}}=12.7 \mathrm{~Hz}, \mathrm{P}-\mathrm{Si}\left(\mathrm{CH}_{3}\right)_{3} \mathrm{ppm} .{ }^{29} \mathrm{Si}\left\{{ }^{1} \mathrm{H}\right\} \mathbf{N M R}\left(243 \mathrm{MHz}, \mathrm{C}_{6} \mathrm{D}_{6}\right): \delta=1.90\right.$ $\left(\mathrm{d},{ }^{2} J_{\mathrm{P}-\mathrm{Si}}=25.4 \mathrm{~Hz}\right) \mathrm{ppm} .{ }^{31} \mathbf{P}\left\{{ }^{1} \mathrm{H}\right\} \mathbf{N M R}\left(243 \mathrm{MHz}, \mathrm{C}_{6} \mathrm{D}_{6}\right): \delta=-69.77(\mathrm{~s}) \mathrm{ppm} .{ }^{31} \mathbf{P}$ NMR $\left(243 \mathrm{MHz}, \mathrm{C}_{6} \mathrm{D}_{6}\right): \delta=-69.77$ (dec., $\left.{ }^{3} J_{\mathrm{P}-\mathrm{Si}(\mathrm{CH} 3) 3}=4.5 \mathrm{~Hz}\right)$ ppm. HRMS (EI, $70 \mathrm{eV}$, MAT95, indirect in $n$-hexane): $m / z$ [M-H] ${ }^{+}$Calcd. for $\mathrm{C}_{27} \mathrm{H}_{27} \mathrm{NPSi} 409.15359$; Found 409.15359. MS (EI): $m / z 409.3(10 \%)[\mathrm{M}]^{+\cdot}, 337.2$ (14\%) [M-TMS] ${ }^{+}, 183.0(45 \%)\left[\mathrm{M}-\mathrm{H},(\mathrm{TMS}),\left(\mathrm{C}_{12} \mathrm{H}_{9}\right)\right]^{+}, 73.1$ $\left.(100 \%){ }^{[T M S}\right]^{+}$.

bis(Biphenyl-2-yl)(trimethyltin)phosphine (H)

The synthesis was conducted similar to [36]: In a glovebox, an inert NMR tube was charged with $\mathbf{D}(10.0 \mathrm{mg}, 29.6 \mu \mathrm{mol})$ and dimethylamino(trimethyl)tin $(15.0 \mathrm{mg}$, $72.0 \mu \mathrm{mol})$. To this, $\mathrm{C}_{6} \mathrm{D}_{6}(0.5 \mathrm{~mL})$ was added and the tube was shaken intensively. The reaction progress was followed by ${ }^{31} \mathrm{P}$ NMR spectroscopy. Since the wanted species was not totally formed the tube was rotated for $2 \mathrm{~h}$ at a rotary evaporator. Afterwards the reaction mixture was dried in vacuo $\left(25^{\circ} \mathrm{C}, 24 \mathrm{~h}, 10^{-3} \mathrm{mbar}\right)$ and the resulting wax $(\mathrm{H}, 14.8 \mathrm{mg}$, $29.5 \mu \mathrm{mol}, 99 \%)$ was isolated. ${ }^{1} \mathbf{H}$ NMR $\left(601 \mathrm{MHz}, \mathrm{C}_{6} \mathrm{D}_{6}\right): \delta=7.59-7.53(\mathrm{~m}, 2 \mathrm{H}, H-3)$, 7.44-7.39 (m, 4H, H-8,12), 7.19-7.16 (m, 2H, H-6), 7.13-7.09 (m, 4H, H-9,11), 7.09-7.02 (m, $4 \mathrm{H}, \mathrm{H}-4, \mathrm{H}-5$ and $\mathrm{H}-10),-0.03\left(\mathrm{~d},{ }^{3} \mathrm{~J}_{\mathrm{P}-\mathrm{SnCH} 33}=1.70 \mathrm{~Hz}, 9 \mathrm{H}, \mathrm{CH}_{3}\right) \mathrm{ppm} .{ }^{13} \mathrm{C}\left\{{ }^{1} \mathbf{H}\right\}$ NMR $\left(151 \mathrm{MHz}, \mathrm{C}_{6} \mathrm{D}_{6}\right): \delta=147.75\left(\mathrm{~d},{ }^{2} J_{\mathrm{C}-\mathrm{P}}=25.6 \mathrm{~Hz}, \mathrm{C}-1\right), 143.00\left(\mathrm{~d},{ }^{3} J_{\mathrm{C}-\mathrm{P}}=4.7 \mathrm{~Hz}, \mathrm{C}-7\right), 137.62$ $\left(\mathrm{d},{ }^{1} J_{\mathrm{C}-\mathrm{P}}=10.1 \mathrm{~Hz}, \mathrm{C}-2\right), 136.68(\mathrm{~s}, \mathrm{C}-3), 131.17\left(\mathrm{~d},{ }^{3} J_{\mathrm{C}-\mathrm{P}}=3.9 \mathrm{~Hz}, \mathrm{C}-6\right), 130.12\left(\mathrm{~d},{ }^{3} J_{\mathrm{C}-\mathrm{P}}=\right.$ $5.0 \mathrm{~Hz}, \mathrm{C}-8,12), 128.32\left(\mathrm{~d},{ }^{3} J_{\mathrm{C}-\mathrm{P}}=7.7 \mathrm{~Hz}, \mathrm{C}-10\right), 127.78$ (s, overlapping with $\mathrm{C}_{6} \mathrm{D}_{6}$ signal, $\mathrm{C}-9,11$ and C-5), $127.45\left(\mathrm{~d},{ }^{4} J_{\mathrm{C}-\mathrm{P}}=42.4 \mathrm{~Hz}, \mathrm{C}-4\right),-7.78\left(\mathrm{~d},{ }^{2} J_{\mathrm{C}-\mathrm{P}}=6.0 \mathrm{~Hz}, \mathrm{P}-\mathrm{Sn}\left(\mathrm{CH}_{3}\right)_{3}\right) \mathrm{ppm}$. ${ }^{31} \mathbf{P}\left\{{ }^{1} \mathbf{H}\right\}$ NMR $\left(243 \mathrm{MHz}, \mathrm{C}_{6} \mathrm{D}_{6}\right): \delta=-61.98\left(\mathrm{~s},{ }^{1} J_{\mathrm{P}-\mathrm{Sn}}\right.$ satellites: $\left.661 \mathrm{~Hz}\right) \mathrm{ppm} .{ }^{119} \mathbf{S n}\left\{{ }^{1} \mathbf{H}\right\}$ NMR $\left(224 \mathrm{MHz}, \mathrm{C}_{6} \mathrm{D}_{6}\right): \delta=0.67\left(\mathrm{~d},{ }^{1} J_{\mathrm{P}-\mathrm{Sn}}=661.8 \mathrm{~Hz}\right) \mathrm{ppm}$. HRMS (EI, $70 \mathrm{eV}$, MAT95, indirect in $n$-hexane): $m / z$ [M-H] ${ }^{+}$Calcd. for $\mathrm{C}_{27} \mathrm{H}_{26} \mathrm{P}^{116} \mathrm{Sn}$ 497.07846; Found 497.07859, [M$\left.\mathrm{CH}_{3}\right]^{+}$Calcd. for $\mathrm{C}_{26} \mathrm{H}_{24} \mathrm{P}^{116} \mathrm{Sn}$ 483.06280; Found 483.06283. MS (EI, giving for ${ }^{120} \mathrm{Sn}$ ): $\mathrm{m} / \mathrm{z}$

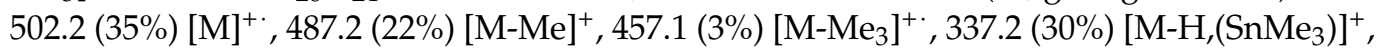
$183.0(100 \%)\left[\mathrm{M}-\mathrm{H},\left(\mathrm{SnMe}_{3}\right),\left(\mathrm{C}_{12} \mathrm{H}_{9}\right)\right]^{+}$.

Supplementary Materials: The following are available online at https:/ / www.mdpi.com/article/ 10.3390/inorganics9110082/s1, all NMR spectra, Table S1: Overview of essential crystal structure details for B, D, E and F. CCDCs 2106887, 2106888, 2106889 and 2108753 contain the supplementary crystallographic data for this paper. These data can be obtained free of charge via http:/ / www.ccdc cam.ac.uk/conts/retrieving.html (or from the CCDC, 12 Union Road, Cambridge CB2 1EZ, UK; Fax: +44 1223 336033; E-mail: deposit@ccdc.cam.ac.uk). 
Author Contributions: Conceptualization, J.H. and A.S.; methodology, J.H.; crystal structure analysis, D.D. and E.L., investigation, J.H.; writing-original draft preparation, J.H. and A.S.; writing-review and editing, J.H. and A.S.; visualization, J.H.; supervision, A.S.; project administration, A.S.; funding acquisition, A.S. All authors have read and agreed to the published version of the manuscript.

Funding: This research was funded by the German Research Foundation (Deutsche Forschungsgemeinschaft DFG), grant number STA1195/2-1.

Acknowledgments: In this section, you can acknowledge any support given which is not covered by the author contribution or funding sections. This may include administrative and technical support, or donations in kind (e.g., materials used for experiments).

Conflicts of Interest: The authors declare no conflict of interest.

\section{References}

1. Staubitz, A.; Hoffmann, J.; Gliese, P. Group 13-Group 15 Element Bonds Replacing Carbon-Carbon Bonds in Main Group Polyolefin Analogs in Smart Inorganic Polymers; Hey-Hawkins, E., Hissler, M., Eds.; Wiley VCH: Weinheim, Germany, 2019 ; pp. 17-39.

2. Dorn, H.; Singh, R.A.; Massey, J.A.; Lough, A.J.; Manners, I. Rhodium-catalyzed formation of phosphorus-boron bonds: Synthesis of the first high molecular weight poly (phosphinoborane). Angew. Chem. Int. Ed. 1999, 38, 3321-3323. [CrossRef]

3. Dorn, H.; Singh, R.A.; Massey, J.A.; Nelson, J.M.; Jaska, C.A.; Lough, A.J.; Manners, I. Transition metal-catalyzed formation of phosphorus-boron bonds: A new route to phosphinoborane rings, chains, and macromolecules. J. Am. Chem. Soc. 2000, 122, 6669-6678. [CrossRef]

4. Gopalakrishnan, J. Aminophosphines: Their chemistry and role as ligands and synthons. Appl. Organomet. Chem. 2009, 23, 291-318. [CrossRef]

5. Zubiri, M.R.I.; Woollins, J.D. Synthesis and uses of phosphines containing P-N bonds. Comments Inorg. Chem. 2003, 24, 189-252. [CrossRef]

6. Dogan, J.; Schulte, J.B.; Swiegers, G.F.; Wild, S.B. Mechanism of phosphorus-carbon bond cleavage by lithium in tertiary phosphines. An optimized synthesis of 1,2-bis (phenylphosphino)ethane. J. Org. Chem. 2000, 65, 951-957. [CrossRef]

7. Bianco, V.D.; Doronzo, S.; Chan, J.; Bennett, M.A. Diphenylphosphine. In Inorganic Syntheses; Basolo, F., Ed.; McGraw Hill Book Company: New York, NY, USA, 1976; pp. 161-163.

8. van Doorn, J.A.; Frijns, J.H.G.; Meijboom, N. Formation and reactions of bis (phosphino) succinic anhydrides. J. Chem. Soc. Perkin Trans. 2 1990, 3, 479-485. [CrossRef]

9. Dingwall, J.G.; Tuck, B. Free radical catalysed additions to the double bond of diketene: A synthesis of novel oxetan-2-ones. J. Chem. Soc. Perkin Trans. 1 1986, 2081-2090. [CrossRef]

10. Cristau, H.-J.; Chêne, A.; Christol, H. Arylation catalytique d'organophosphorés. Produits de l'arylation, catalysée par les sels de nickel (II), de composés du phosphore tricoordiné. J. Organomet. Chem. 1980, 185, 283-295. [CrossRef]

11. Gilbertson, S.R.; Starkey, G.W. Palladium-catalyzed synthesis of phosphine-containing amino acids. J. Org. Chem. 1996, 61, 2922-2923. [CrossRef]

12. Martorell, G.; Garcías, X.; Janura, M.; Saá, J.M. Direct palladium-catalyzed phosphinylation of aryl triflates with secondary phosphines. Its scope and limitations: The synthesis of optically active carboxylated 2-(diphenylphosphino)-1,1'-binaphthalenes. J. Org. Chem. 1998, 63, 3463-3467. [CrossRef]

13. Zhao, Y.L.; Wu, G.J.; Li, Y.; Gao, L.X.; Han, F.S. [NiCl 2 (dppp)]—Catalyzed cross-coupling of aryl halides with dialkyl phosphite, diphenylphosphine oxide, and diphenylphosphine. Chemistry 2012, 18, 9622-9627. [CrossRef]

14. Leone-Bay, A. Lithium diphenylphosphide as a reagent for the dehydroxylation of alpha-hydroxy ketones. J. Org. Chem. 2002, 51, 2378-2379. [CrossRef]

15. Mann, F.G.; Tong, B.P.; Wystrach, V.P. 213. The abnormal hydrolysis of certain $\beta$-diarylphosphinopropionic esters. Part II. Correction and extension. J. Chem. Soc. 1963, 1155-1167. [CrossRef]

16. Mann, F.G.; Pragnell, M.J. 761. The dealkylation of alkyl aryl ethers and sulphides by diaryl-phosphide and -arsenide ions. J. Chem. Soc. 1965, 4120-4127. [CrossRef]

17. Staubitz, A.; Robertson, A.P.; Sloan, M.E.; Manners, I. Amine- and phosphine-borane adducts: New interest in old molecules. Chem. Rev. 2010, 110, 4023-4078. [CrossRef] [PubMed]

18. Carboni, B.; Monnier, L. Recent developments in the chemistry of amine- and phosphine-boranes. Tetrahedron 1999, 55, 1197-1248. [CrossRef]

19. Carroll, L.; Boldon, S.; Bejot, R.; Moore, J.E.; Declerck, J.; Gouverneur, V. The traceless staudinger ligation for indirect 18Fradiolabelling. Org. Biomol. Chem. 2011, 9, 136-140. [CrossRef]

20. Juge, S.; Stephan, M.; Laffitte, J.A.; Genet, J.P. Efficient asymmetric synthesis of optically pure tertiary mono and diphosphine ligands. Tetrahedron Lett. 1990, 31, 6357-6360. [CrossRef]

21. Bernoud, E.; Alayrac, C.; Delacroix, O.; Gaumont, A.C. Copper-catalyzed synthesis of alkynylphosphine derivatives: Unprecedented use of nucleophilic phosphorus compounds. Chem. Commun. 2011, 47, 3239-3241. [CrossRef] 
22. Lipshutz, B.H.; Buzard, D.J.; Yun, C.S. Pd (0)-mediated couplings of aryl nonaflates and triflates with diphenylphosphine-borane. Preparation of bh3-stabilized, unsymmetrical triarylphosphines. Tetrahedron Lett. 1999, 40, 201-204. [CrossRef]

23. Julienne, D.; Lohier, J.F.; Delacroix, O.; Gaumont, A.C. Palladium-catalyzed C-P coupling reactions between vinyl triflates and phosphine-boranes: Efficient access to vinylphosphine-boranes. J. Org. Chem. 2007, 72, 2247-2250. [CrossRef]

24. Gilbertson, S.R.; Fu, Z.; Starkey, G.W. Palladium-catalyzed synthesis of vinyl phosphines from ketones. Tetrahedron Lett. 1999, 40, 8509-8512. [CrossRef]

25. Ueda, S.; Ali, S.; Fors, B.P.; Buchwald, S.L. $\mathrm{Me}_{3}(\mathrm{OMe}) t$ BuXPhos: A surrogate ligand for $\mathrm{Me}_{4} t$ BuXPhos in palladium-catalyzed C-N and C-O bond-forming reactions. J. Org. Chem. 2012, 77, 2543-2547. [CrossRef]

26. Hoshiya, N.; Buchwald, S.L. An improved synthesis of BrettPhos and RockPhos-type biarylphosphine ligands. Adv. Synth. Catal. 2012, 354, 2031-2037. [CrossRef]

27. Su, M.; Buchwald, S.L. A bulky biaryl phosphine ligand allows for palladium-catalyzed amidation of five-membered heterocycles as electrophiles. Angew. Chem. Int. Ed. 2012, 51, 4710-4713. [CrossRef]

28. Salvi, L.; Davis, N.R.; Ali, S.Z.; Buchwald, S.L. A new biarylphosphine ligand for the Pd-catalyzed synthesis of diaryl ethers under mild conditions. Org. Lett. 2012, 14, 170-173. [CrossRef]

29. Schweizer, S.; Becht, J.-M.; Le Drian, C. Development of efficient and reusable diarylphosphinopolystyrene-supported palladium catalysts for C-C bond forming cross-coupling reactions. Adv. Synth. Catal. 2007, 349, 1150-1158. [CrossRef]

30. Siedzielnik, M.; Kaniewska-Laskowska, K.; Szynkiewicz, N.; Chojnacki, J.; Grubba, R. Reactivity of bulky aminophosphanes towards small molecules: Activation of dihydrogen and carbon dioxide by aminophosphane/borane frustrated lewis pairs. Polyhedron 2021, 194, 114930. [CrossRef]

31. Levin, M.D.; Toste, F.D. Gold-catalyzed allylation of aryl boronic acids: Accessing cross-coupling reactivity with gold. Angew. Chem. Int. Ed. 2014, 53, 6211-6215. [CrossRef]

32. Alajarín, M.; López-Leonardo, C.; Llamas-Lorente, P. The chemistry of phosphinous amides (aminophosphanes): Old reagents with new applications. Top. Curr. Chem. 2005, 250, 77-106.

33. Zhang, W.; Wu, H.; Liu, Z.; Zhong, P.; Zhang, L.; Huang, X.; Cheng, J. The use of calcium carbide in one-pot synthesis of symmetric diaryl ethynes. Chem. Commun. 2006, 46, 4826-4828. [CrossRef]

34. Lamola, J.L.; Shilubana, J.C.; Ngodwana, L.; Vatsha, B.; Adeyinka, A.S.; Maumela, M.C.; Holzapfel, C.W.; Mmutlane, E.M. Easily prepared mono (N, N-dialkylamino) phosphine palladium (II) complexes: Structural and catalytic evaluation. Eur. J. Inorg. Chem. 2021, 2021, 2578-2582. [CrossRef]

35. Dyer, P.W.; Fawcett, J.; Hanton, M.J.; Kemmitt, R.D.W.; Padda, R.; Singh, N. Exploring the coordination chemistry and reactivity of dialkylamino- and bis(dialkylamino)-phosphines in the coordination sphere of metals. Dalton Trans. 2003, 1, 104-113. [CrossRef]

36. Li, Y.; Chakrabarty, S.; Muck-Lichtenfeld, C.; Studer, A. Ortho-trialkylstannyl arylphosphanes by C-P and C-Sn bond formation in arynes. Angew. Chem. Int. Ed. 2016, 55, 802-806. [CrossRef]

37. Balakrishna, M.S.; Abhyankar, R.M.; Mague, J.T. New bis(phosphines) derived from N, $\mathrm{N}^{\prime}$-substituted ethylenediamine derivatives. Synthesis and transition metal chemistry of $\mathrm{X}_{2} \mathrm{PN}(\mathrm{R}) \mathrm{CH}_{2} \mathrm{CH}_{2}(\mathrm{R}) \mathrm{NPX}_{2}\left(\mathrm{R}=\mathrm{CH}_{2} \mathrm{Ph}\right.$ or $\mathrm{Ph}, \mathrm{X}=\mathrm{Ph}$; $\left.\mathrm{R}=\mathrm{CH}_{2} \mathrm{Ph}, \mathrm{X}_{2}=\mathrm{O}_{2} \mathrm{C}_{6} \mathrm{H}_{4}\right)$. The crystal and molecular structure of $\mathrm{Ph}_{2} \mathrm{PN}\left(\mathrm{CH}_{2} \mathrm{Ph}\right) \mathrm{CH}_{2} \mathrm{CH}_{2}\left(\mathrm{CH}_{2} \mathrm{Ph}_{2} \mathrm{NPPh}_{2}\right.$ and cis$\left[\left\{\mathrm{PtCl}_{2} \mathrm{Ph}_{2} \mathrm{PN}\left(\mathrm{CH}_{2} \mathrm{Ph}\right) \mathrm{CH}_{2} \mathrm{CH}_{2}\left(\mathrm{CH}_{2} \mathrm{Ph}\right) \mathrm{NPPh}_{2}\right\}\right]$. J. Chem. Soc. Dalton Trans. 1999, 9, 1407-1412.

38. Surry, D.S.; Buchwald, S.L. Dialkylbiaryl phosphines in Pd-catalyzed amination: A user's guide. Chem. Sci. 2011, 2, 27-50. [CrossRef]

39. Barder, T.E.; Buchwald, S.L. Rationale behind the resistance of dialkylbiaryl phosphines toward oxidation by molecular oxygen. J. Am. Chem. Soc. 2007, 129, 5096-5101. [CrossRef]

40. MacInnis, M.C.; McDonald, R.; Turculet, L. Synthesis and characterization of palladium complexes supported by an NPNphosphido ancillary ligand. Organometallics 2011, 30, 6408-6415. [CrossRef]

41. Izod, K.; Evans, P.; Waddell, P.G. Desolvation and aggregation of sterically demanding alkali metal diarylphosphides. Dalton Trans. 2017, 46, 13824-13834. [CrossRef]

42. Kurz, S.; Hey-Hawkins, E. Synthesis and crystal structure of $\left[\left\{\mathrm{Li}\left(2,4,6 \text {-tert- } \mathrm{Bu}_{3} \mathrm{C}_{6} \mathrm{H}_{2}\right)\right\}\left\{\mathrm{LiP}(\mathrm{H})\left(2,4,6 \text {-tert-Bu } 3 \mathrm{C}_{6} \mathrm{H}_{2}\right)\right\}\right]_{2}$ : A compound with an unusual (lithium-phosphorus-lithium-carbon) $)_{2}$ eight-membered ring. Organometallics 2002, 11, 2729-2732. [CrossRef]

43. Rivard, E.; Sutton, A.D.; Fettinger, J.C.; Power, P.P. Synthesis of the sterically congested diarylphosphines ArTrip2P(Ph) H (ArTrip2 $\left.=\mathrm{C}_{6} \mathrm{H}_{3}-2,6\left(\mathrm{C}_{6} \mathrm{H}_{2}-2,4,6-\mathrm{Pr}_{3}{ }_{3}\right)\right)$ and $\operatorname{ArMes}_{2} \mathrm{P}(\mathrm{Ph}) \mathrm{H}\left(\mathrm{ArMes}_{2}=\mathrm{C}_{6} \mathrm{H}_{3}-2,6\left(\mathrm{C}_{6} \mathrm{H}_{2}-2,4,6-\mathrm{Me}_{3}\right)\right)$ and the monomeric Sn (II)-diphosphide [ArMes $2 \mathrm{P}(\mathrm{Ph})]_{2}$ Sn. Inorg. Chim. Acta 2007, 360, 1278-1286. [CrossRef]

44. Bodach, A.; Hebestreit, R.; Bolte, M.; Fink, L. Syntheses and crystal structures of phenyl-lithium derivatives. Inorg. Chem. 2018, 57, 9079-9085. [CrossRef]

45. Hey, E.; Hitchcock, P.B.; Lappert, M.F.; Rai, A.K. Bis (trimethylsilyl) phosphidometal complexes. J. Organomet. Chem. 1987, 325, 1-12. [CrossRef]

46. Mulvey, E.R.; Wade, K.; Armstrong, R.D.; Walker, T.G.; Snaith, R.; Clegg, W.; Reed, D. X-ray crystallographic and solution studies of the pentamethyldiethylenetriamine and tetramethylethylenediamine adducts of lithium diphenylphosphide. Polyhedron 1987, 6, 987-993. [CrossRef]

47. Campbell, I.G.M.; Fowles, G.W.A.; Nixon, L.A. 267. Organometallic compounds containing a tin-phosphorus bond. J. Chem. Soc. 1964, 1389-1396. [CrossRef] 
48. Dolomanov, O.V.; Bourhis, L.J.; Gildea, R.J.; Howard, J.A.K.; Puschmann, H. Olex2: A complete structure solution, refinement and analysis program. J. Appl. Crystallogr. 2009, 42, 339-341. [CrossRef]

49. Macrae, C.F.; Sovago, I.; Cottrell, S.J.; Galek, P.T.A.; McCabe, P.; Pidcock, E.; Platings, M.; Shields, G.P.; Stevens, J.S.; Towler, M.; et al. Mercury 4.0: From visualization to analysis, design and prediction. J. Appl. Crystallogr. 2020, 53, 226-235. [CrossRef]

50. Han, S.; Harris, C.M.; Harris, T.M.; Kim, H.-Y.H.; Kim, S.J. Synthesis of deoxyadenosine $3^{\prime}$-phosphates bearingcisandtransadducts of $7 \beta, 8 \alpha$-dihydroxy-9 $\alpha, 10 \alpha$-epoxy-7,8,9,10-tetrahydrobenzo[a]pyrene: Standards for 32P-Postlabeling assays. J. Org. Chem. 1996, 61, 174-178. [CrossRef] 